\title{
The exchange of carbon dioxide between wet arctic tundra and the atmosphere at the Lena River Delta, Northern Siberia
}

\author{
L. Kutzbach ${ }^{1, *}$, C. Wille ${ }^{1, *}$, and E.-M. Pfeiffer ${ }^{2}$ \\ ${ }^{1}$ Alfred Wegener Institute for Polar and Marine Research, Research Unit Potsdam, Telegrafenberg A43, 14473 Potsdam, \\ Germany \\ ${ }^{2}$ University of Hamburg, Institute of Soil Science, Allende-Platz 2, 20146 Hamburg, Germany \\ * now at Ernst Moritz Arndt University Greifswald, Institute for Botany and Landscape Ecology, Grimmer Straße 88, 17487 \\ Greifswald, Germany
}

Received: 23 May 2007 - Published in Biogeosciences Discuss.: 25 June 2007

Revised: 1 October 2007 - Accepted: 8 October 2007 - Published: 18 October 2007

\begin{abstract}
The exchange fluxes of carbon dioxide between wet arctic polygonal tundra and the atmosphere were investigated by the micrometeorological eddy covariance method. The investigation site was situated in the centre of the Lena River Delta in Northern Siberia $\left(72^{\circ} 22^{\prime} \mathrm{N}, 126^{\circ} 30^{\prime} \mathrm{E}\right)$. The study region is characterized by a polar and distinctly continental climate, very cold and ice-rich permafrost and its position at the interface between the Eurasian continent and the Arctic Ocean. The soils at the site are characterized by high organic matter content, low nutrient availability and pronounced water logging. The vegetation is dominated by sedges and mosses. The micrometeorological campaigns were performed during the periods July-October 2003 and May-July 2004 which included the period of snow and soil thaw as well as the beginning of soil refreeze. The main $\mathrm{CO}_{2}$ exchange processes, the gross photosynthesis and the ecosystem respiration, were found to be of a generally low intensity. The gross photosynthesis accumulated to $-432 \mathrm{~g} \mathrm{~m}^{-2}$ over the photosynthetically active period (June-September). The contribution of mosses to the gross photosynthesis was estimated to be about $40 \%$. The diurnal trend of the gross photosynthesis was mainly controlled by the incoming photosynthetically active radiation. During midday, the photosynthetic apparatus of the canopy was frequently near saturation and represented the limiting factor on gross photosynthesis. The synoptic weather conditions strongly affected the exchange fluxes of $\mathrm{CO}_{2}$ by changes in cloudiness, precipitation and pronounced changes of air temperature. The ecosystem respiration accumulated to $+327 \mathrm{~g} \mathrm{~m}^{-2}$ over the photosynthetically active period, which corresponds to $76 \%$ of the $\mathrm{CO}_{2}$ uptake by photosynthesis. However, the ecosystem res-
\end{abstract}

Correspondence to: L. Kutzbach

(kutzbach@uni-greifswald.de) piration continued at substantial rates during autumn when photosynthesis had ceased and the soils were still largely unfrozen. The temporal variability of the ecosystem respiration during summer was best explained by an exponential function with surface temperature, and not soil temperature, as the independent variable. This was explained by the major role of the plant respiration within the $\mathrm{CO}_{2}$ balance of the tundra ecosystem. The wet polygonal tundra of the Lena River Delta was observed to be a substantial $\mathrm{CO}_{2}$ sink with an accumulated net ecosystem $\mathrm{CO}_{2}$ exchange of $-119 \mathrm{~g} \mathrm{~m}^{-2}$ over the summer and an estimated annual net ecosystem $\mathrm{CO}_{2}$ exchange of $-71 \mathrm{~g} \mathrm{~m}^{-2}$.

\section{Introduction}

There is growing evidence that the climate system of the earth has changed significantly since the industrial revolution. The observed climate change is likely to be caused at least partially by human activity, which has substantially altered the atmospheric composition by the emission of radiatively active greenhouse gases such as carbon dioxide and methane (IPCC, 2007). The Arctic is of major interest within the context of global change because it is observed to warm more rapidly and to a greater extent than the rest of the earth surface (Maxwell, 1997; Serreze et al., 2000; Polyakov et al., 2003), and much larger changes are projected by climate model simulations (Kattenberg et al., 1996; Räisänen, 2001). Furthermore, its ecosystems are highly sensitive to climate change (Chapin et al., 1992; Oechel et al., 1997b) and play a key role in many global processes, such as the atmospheric and oceanic circulations (Stocker and Schmittner, 1997; Wood et al., 1999; Eugster et al., 2000)

Published by Copernicus Publications on behalf of the European Geosciences Union. 
or the regulation of the global budget of greenhouse gases (Gorham, 1991; Roulet et al., 1992; Tenhunen, 1996).

Most land surfaces in the Arctic are covered by tundra, treeless ecosystems whose vegetation consists primarily of grasses, sedges, small flowering herbs, low shrubs, lichens and mosses. Arctic and alpine tundra occupy $7.4 \times 10^{6} \mathrm{~km}^{2}$ or about $7.4 \%$ of the land area of the northern hemisphere (Matthews, 1983; Loveland et al., 2000). Since the biota of the arctic ecosystems are closely adapted to their extreme environment, climatic changes will have a severe impact on the distribution, composition and functionality of plant and animal communities in the tundra (Callaghan and Jonasson, 1995; Chapin et al., 1995, 1997; Walker et al., 2001). This will cause major alterations of the energy, water and carbon balance of the Arctic land surfaces, which will feed back on the atmospheric system of the Arctic (Zhuang et al., 2006; Sturm et al, 2001b; Chapin et al., 2005). While the carbon balance changes in northern ecosystems are estimated to have only minor feedback effects on the global climate in the context of the projected anthropogenic carbon emissions (Zhuang et al., 2006), the changes of the water and energy balance by hydrological and vegetation changes in the Arctic are expected to be significant also on the global scale (Bonan et al., 1995; Lafleur and Rouse, 1995; Pielke and Vidale, 1995; Bröcker, 1997; Beringer et al., 2001; Peterson et al., 2002).

The tundra ecosystems are underlain by permafrost. Permafrost-affected soils often have a greater content of organic carbon than soils of temperate climate zones because organic matter decomposition is inhibited by cold temperatures, a short growing season, and water saturated soils. Correspondingly, the tundra ecosystems have historically been major sinks for carbon and nutrients. At least $14 \%$ of the global soil organic carbon is stored in the tundra (Post et al., 1982; Billings, 1987). However, permafrost is very susceptible to long-term warming, and an increased level of permafrost thawing might turn the tundra from a carbon sink to a source of carbon, either in the form of $\mathrm{CO}_{2}$ or as $\mathrm{CH}_{4}$ (Oechel et al., 1993; Christensen, 1993; Zimov et al., 1997). Since $\mathrm{CO}_{2}$ and $\mathrm{CH}_{4}$ are the most effective greenhouse gases besides water vapour (Rohde, 1990), an increased release of these gases by permafrost thawing would additionally amplify global warming.

In the last decade, numerous land-atmosphere flux studies relying on the eddy covariance method have been initiated, for example within the projects NOWES (Glooschenko, 1994), ABLE 3B (Harriss et al., 1994), BOREAS (Sellers et al., 1997), NOPEX (Halldin et al., 1999) or EUROFLUX (Valentini, 2002). Most of the eddy covariance flux studies were and are conducted in the temperate and boreal zones of North America and Europe. Flux data for the Arctic regions are limited and are biased toward Alaska and Northern Fennoscandia. However, the vast tundra landscapes of Siberia are by far not adequately represented. This study presents the results of two micrometeorological field cam- paigns which were conducted in the wet arctic tundra of the North-Siberian Lena River Delta in 2003 and 2004. The study shall contribute to the understanding of the physical and biogeochemical interaction processes between permafrost soils, tundra vegetation, and the atmosphere which is necessary for assessing the impact of climate change on arctic tundra ecosystems and the possible feedbacks on the climate system. The objectives of the study were to characterize the exchange fluxes of $\mathrm{CO}_{2}$ on diurnal and seasonal time scales, to quantify gross photosynthesis, ecosystem respiration and net ecosystem $\mathrm{CO}_{2}$ exchange on the landscape scale, to analyze the regulation of the exchange fluxes by climatic forcings, and to estimate the annual $\mathrm{CO}_{2}$ budget of the tundra ecosystem.

\section{Materials and methods}

\subsection{Study site}

The investigation site was located on Samoylov Island in the Lena River Delta at $72^{\circ} 22^{\prime} \mathrm{N}, 126^{\circ} 30^{\prime} \mathrm{E}$. With an area of $32000 \mathrm{~km}^{2}$, the Lena River Delta is the largest delta in the Arctic and one of the largest in the world (Walker, 1998). In terms of its geological genesis, the Lena River Delta can be divided in three river terraces of different age, and various floodplain levels (Grigoriev, 1993; Schwamborn et al., 2002). The youngest terraces and active flood-plains which represent modern delta landscapes (Are and Reimnitz, 2000) occupy about $65 \%$ of the total area of the delta, predominantly in the central and eastern part (Fig. 1).

The Lena River Delta is located in the zone of continuous permafrost with permafrost depths of about $500 \mathrm{~m}$ (Grigoriev, 1960; Frolov, 2003; Zhang et al., 1999; NSIDC, 2003). With about $-12^{\circ} \mathrm{C}$, the permafrost temperature is very low. Colder permafrost is only encountered on the Taymyr Peninsula to the North-West of the Lena River Delta and on the Canadian Arctic Archipelago (Natural Resources Canada, 1995; Kotlyakov and Khromova, 2002). The soils of the region thaw to a depth of only $0.3-1.0 \mathrm{~m}$ during the summer.

The climate in the Lena River Delta is characterized by very low temperatures and low precipitation. The mean annual air temperature during 1961-1999, measured by the meteorological station in Tiksi about $100 \mathrm{~km}$ east of Samoylov Island was $-13.6^{\circ} \mathrm{C}$, the mean annual precipitation in the same period was $319 \mathrm{~mm}$ (ROSHYDROMET, 2004). Data from the meteorological station on Samoylov Island from the period 1999-2005 showed a mean annual air temperature of $-14.7^{\circ} \mathrm{C}$ and a highly variable total summer precipitation (rain) between 72 and $208 \mathrm{~mm}$ (mean $137 \mathrm{~mm}$ ) (Boike et al., $2007^{1}$ ). Polar day begins at 7 May and ends at 7 August,

\footnotetext{
${ }^{1}$ Boike, J., Wille, C., and Abnizova, A.: The climatology, and summer energy and water balance of polygonal tundra in the Lena River Delta, Siberia, J. Geophys. Res.-Biogeosciences, in review, 2007.
} 


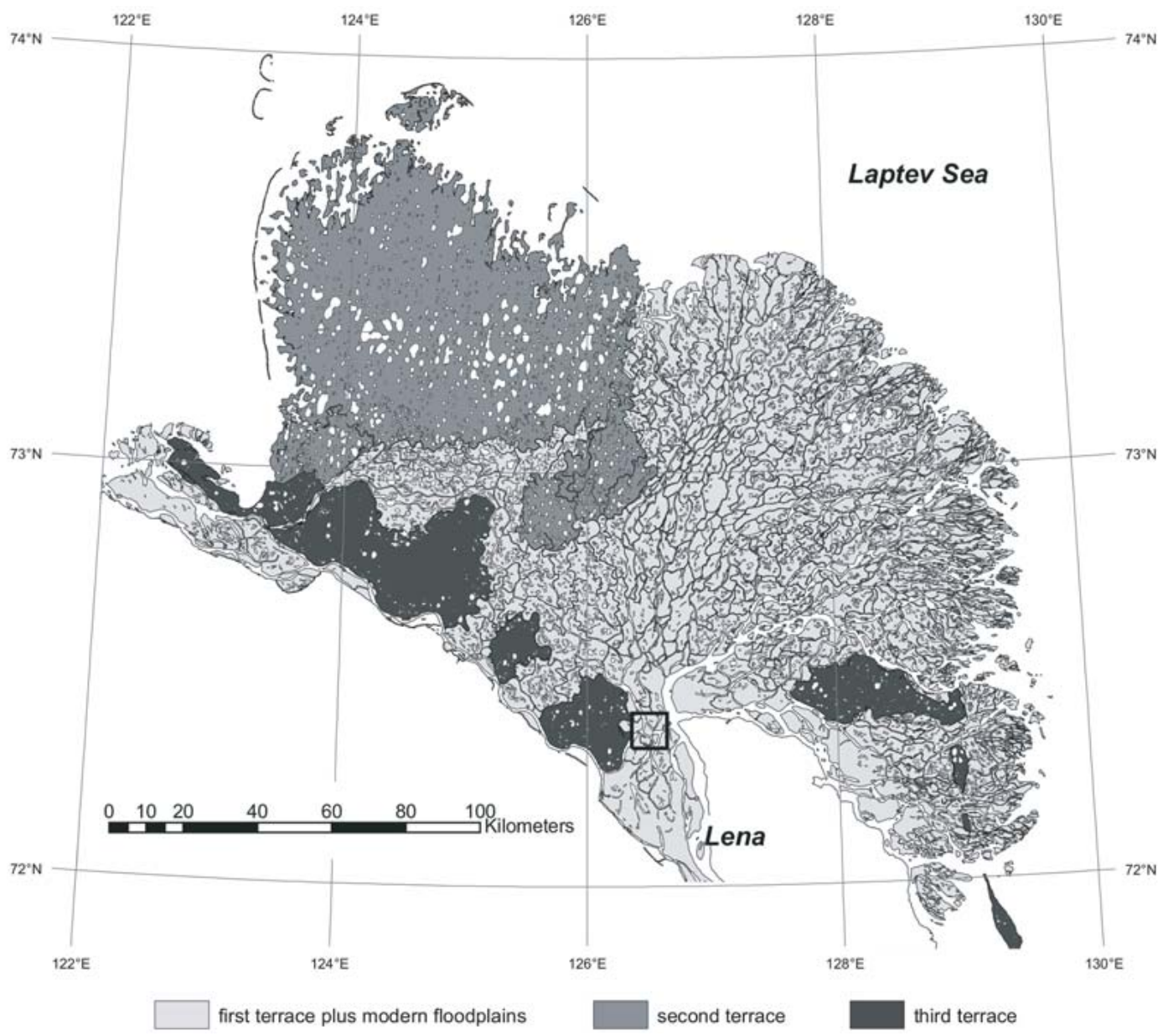

Fig. 1. Map of the Lena River Delta. The location of the investigation area Samoylov Island is marked by a square. Geomorphological units are according to Grigoriev (1993).

and polar night lasts from 15 November to 28 January. The summer growing season lasts about three months, from the middle of June to the middle of September. The synoptic weather conditions in the Lena River Delta are characterized by its position at the border between the Arctic Ocean and the Siberian mainland. During summer, the central delta region experiences strongly varying weather conditions due to the change between the advection of cold and moist air masses from the Arctic Ocean, and warm and dry air masses from the Siberian mainland.

Samoylov Island is situated in the southern-central part of the Lena River Delta and is considered to be representative for the modern delta landscapes. It has a size of $7.5 \mathrm{~km}^{2}$ and is composed of two geomorphological units. The western part $\left(3.4 \mathrm{~km}^{2}\right)$ represents a modern floodplain which is flooded annually during the spring flood. The investigation site was located on the eastern part of Samoylov $\left(4.1 \mathrm{~km}^{2}\right)$, which is composed of the sediments of the Late-Holocene river terrace. Its elevation ranges from 10 to $16 \mathrm{~m}$ a.s.l., and it is not flooded annually. Its surface is characterized by wet polygonal tundra. The macro-relief of the eastern part of Samoylov Island is level with slope gradients less than $0.2 \%$. Only along the shorelines of the larger lakes, elevation differences of up to $2.5 \mathrm{~m}$ occur. However, the surface of the terrace is structured by a regular micro-relief with elevation differences of up to $0.5 \mathrm{~m}$ within a few meters, which is caused by the genesis of low-centred ice wedge polygons (Washburn, 1979; French, 1996; Meyer, 2003). The depressed centres of the ice-wedge polygons are surrounded by elevated rims, which are situated above the ice-wedges. The formation of low-centred polygons has a strong impact on the water regime and the ecological conditions of the tundra landscape. In the depressed polygon centres, drainage is impeded due to the underlying permafrost, and watersaturated soils or small ponds occur. In contrast, the elevated polygon rims are characterized by a moderately moist water regime. The typical soil types are Typic Historthels in the polygon centres and Glacic or Typic Aquiturbels at the polygon rims, respectively (Soil Survey Staff, 1998). The vegetation in the polygon centres and at the edge of ponds 


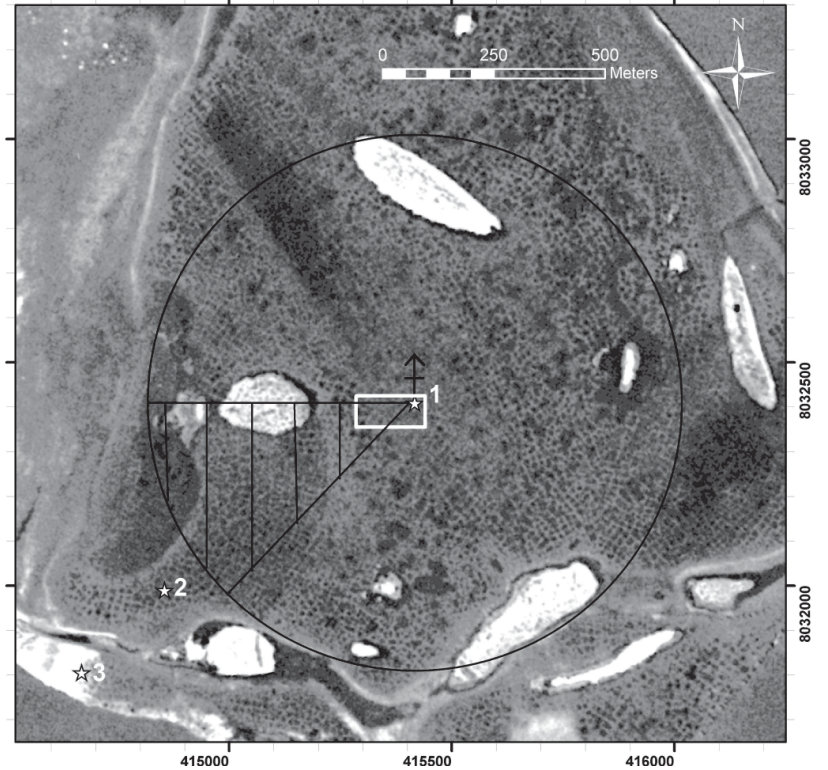

Fig. 2. CORONA satellite image of Samoylov Island, taken on 22 June 1964. The star symbols mark the position of (1) the eddy covariance system, (2) the long-term meteorological and soil station, and (3) the field laboratory. The black circle marks the $600 \mathrm{~m}$ radius around the eddy tower, and the hatched area marks the sector of discarded data due to disturbance from the power generator.

is dominated by hydrophytic sedges (Carex aquatilis, Carex chordorrhiza, Carex rariflora) and mosses (e.g. Limprichtia revolvens, Meesia longiseta, Aulacomnium turgidum). At the polygon rims, various mesophytic dwarf shrubs (e.g. Dryas octopetala, Salix glauca), forbs (e.g. Astragalus frigidus) and mosses (e.g. Hylocomium splendens, Timmia austriaca) dominate. The maximum summer leave coverage of the vascular plants was estimated to be about 0.3 , both at the polygon centres and the polygon rims (Kutzbach, 2000). The leave coverage of the mosses was estimated to be about 0.95 at the polygon centres and rims. More detailed characterizations of the typical soil and vegetation types of the polygonal tundra on Samoylov Island was given by Pfeiffer et al. (2002), Kutzbach (2000), Kutzbach et al. (2003, 2004a) and Fiedler et al. (2004). Aerial photograph analysis showed that the elevated dry to moist polygon rims contribute about $60 \%$ and the depressed wet sites, i.e. polygon centres and troughs, $40 \%$ to the total area of the polygonal tundra in the fetch area around the micrometeorological tower (G. Grosse, personal communication, 2005).

\subsection{Experimental set-up}

Micrometeorological measurements were carried out during the periods 20 July-22 October 2003 (94 complete days), and 28 May-20 July 2004 (53 complete days). The eddy covariance measurement system was established at a central position within the wet polygonal tundra of the eastern part of Samoylov Island. Wet polygonal tundra extended at least $600 \mathrm{~m}$ in all directions from the eddy tower (Fig. 2). The three-dimensional wind vector and the sonic temperature were measured with a sonic anemometer (Solent R3, Gill Instruments Ltd., UK) at a height of $3.65 \mathrm{~m}$ above ground level. The concentration of $\mathrm{H}_{2} \mathrm{O}$ and $\mathrm{CO}_{2}$ were measured with a closed-path infrared gas analyser (LI-7000, LI-COR Inc., USA). The gas analyzer was installed in a temperatureregulated case at the foot of the tower. The sample air intake was placed $15 \mathrm{~cm}$ below the centre of the sonic anemometer transducer array. From the intake, sample air was drawn at a rate of $20 \mathrm{~L} \mathrm{~min}^{-1}$ through a heated Polyethylene tube of $5 \mathrm{~m}$ length and $6.35 \mathrm{~mm}$ inner diameter to the gas analyzer. Under these conditions, turbulent flow was maintained inside the tubing system. A $1 \mu \mathrm{m}$ membrane filter (PTFE, TE37, Schleicher \& Schuell, Germany) prevented dust contamination. The analogous signals from the fast response sensors were digitized at a frequency of $20 \mathrm{~Hz}$ by the anemometer and logged by a laptop computer running the software EdiSol (J. Massheder, University of Edinburgh, UK). Power was supplied by a diesel generator which was placed at a distance of $100 \mathrm{~m}$ from the tower. Wooden boardwalks connected all parts of the system to reduce disturbance of the swampy tundra soils and the vegetation. All equipment was set up in a line to the west-southwest from the tower.

In addition to the fast-response eddy covariance measurements, a set of supporting slow-response meteorological measurements were conducted. The meteorological data were partly recorded at the eddy tower site and partly provided by a long-term meteorological station (Boike et al., $2007^{1}$ ), which is located $700 \mathrm{~m}$ away from the eddy site in the polygonal tundra of Samoylov Island (Fig. 2). At the eddy tower were measured: air temperature and air relative humidity at $2 \mathrm{~m}$ height (MP103A, ROTRONIC AG, Switzerland), incoming and surface-reflected solar and infrared radiation (CNR1, Kipp \& Zonen B.V., The Netherlands), and air pressure (RPT410, Druck Messtechnik GmbH, Germany). From the incoming solar radiation $S \downarrow$, the photosynthetically active radiation PAR was estimated using the equation

$\mathrm{PAR}=S \downarrow \cdot 0.45 \cdot 4.598 \mu \mathrm{mol} \mathrm{J}^{-1}$.

This method follows Jacovides et al. (2003) and was shown to work very accurately by direct comparison of solar radiation and PAR sensors during a measurement campaign in the Lena River Delta in 2005 (data not shown). The long-term meteorological station recorded precipitation (tipping bucket rain gauge 52203, R.M. Young Company, USA), snow height at a polygon centre (sonic ranging sensor SR50, Campbell Scientific Inc., USA), horizontal wind speed and direction at $3 \mathrm{~m}$ height (propeller anemometer 05103, R.M. Young Company, USA), air temperature and relative humidity at $0.5 \mathrm{~m}$ and $2 \mathrm{~m}$ height (MP103A, ROTRONIC AG, Switzerland), net radiation (NR-Lite, Kipp \& Zonen B.V., The Netherlands), and upward infrared radiation (CG1, Kipp \& Zonen B.V., The Netherlands). From the upward infrared radiation 
$L \uparrow_{B}$, the radiative surface temperature $T_{\text {sur }}$ was calculated using the formula

$T_{\text {sur }}=\left(\frac{L \uparrow_{B}}{\varepsilon 5.67 \times 10^{-8}}\right)^{1 / 4}$,

where the emissivity $\varepsilon$ was assumed to be 0.98 . Profiles of soil temperature and soil volumetric water content were measured at the elevated rim and the depressed centre of a polygon (temperature probe 107 and TDR100/CS605, respectively, Campbell Scientific Inc., USA). Water level depth was measured manually in intervals of 1 to 3 days in perforated plastic pipes, which were installed in the soil active layer at three soil survey sites in the vicinity of the eddy tower. Thaw depth was measured in intervals of 3 to 7 days at 150 points arranged in a regular grid by driving a steel rod into the unfrozen soil until the hard frozen permafrost table was encountered (Kutzbach et al., 2004b).

\subsection{Processing of eddy covariance data}

Turbulent fluxes were calculated over $30 \mathrm{~min}$ averaging intervals using the software EdiRe (R. Clement, University of Edinburgh, UK). Three coordinate rotations were applied to the wind vector components so that the mean transverse velocity, the mean vertical velocity, and the covariance of the transverse and vertical velocities were reduced to zero for each 30 min interval (McMillen, 1988; Aubinet et al., 2000). The time series of the $\mathrm{CO}_{2}$ gas concentration was detrended using a recursive high-pass filter with a filter constant of $300 \mathrm{~s}$ (McMillen, 1988). The time lag between the signals of $\mathrm{CO}_{2}$ concentration and vertical wind velocity was determined and removed for each $30 \mathrm{~min}$ interval. After the calculation of the $\mathrm{CO}_{2}$ flux, transfer functions were applied to account for the spectral response of the gas analyzer, the separation of the sensors, the damping effect of the gas sampling tube and the detrending filter (Moore, 1986; Moncrieff et al., 1997). On average, the percentage of this correction compared to the uncorrected $\mathrm{CO}_{2}$ flux was $8.5 \%$. Additionally, the $\mathrm{CO}_{2}$ flux was corrected for effects of concurrent water vapour fluxes on the density of air (Webb et al., 1980).

The calculated flux data was screened thoroughly. Data points were rejected when sensor outputs were out of range and when instruments were being repaired or calibrated. Turbulence was considered insufficient when the mean friction velocity was below $0.1 \mathrm{~m} \mathrm{~s}^{-1}$. Data gathered during periods with wind directions in the sector $230^{\circ}-270^{\circ}$ were discarded because of the possible disturbance by the generator. Altogether, $31 \%$ and $26 \%$ of the calculated $\mathrm{CO}_{2}$ fluxes were rejected in 2003 and 2004, respectively, which is comparable to other studies (Falge et al., 2001). The turbulent fluxes calculated over $30 \mathrm{~min}$ intervals were averaged over $60 \mathrm{~min}$ for compatibility with the meteorological data of the long-term meteorological station. The gaps in the data series produced by the screening procedure were filled by means of models based on empirical relationships between the turbulent fluxes and meteorological variables. The model approach is described below.

A footprint analysis following Schuepp et al. (1990) assessed the $80 \%$ cumulative footprint, i.e. the upwind distance from which $80 \%$ of the observed flux originated, to be on average $457 \mathrm{~m}$ during the snow-free periods, and $781 \mathrm{~m}$ during periods when snow covered the surface.

\subsection{Modelling of carbon dioxide fluxes}

The calculated carbon dioxide flux $F_{\mathrm{CO} 2}$ equals the net ecosystem $\mathrm{CO}_{2}$ exchange NEE which is the sum of gross photosynthesis $P_{\text {gross }}$ and ecosystem respiration $R_{\text {eco }}$. The ecosystem respiration is composed of the respiration from soil microbes $R_{\text {soil }}$, roots $R_{\text {roots }}$, and above-ground biomass $R_{\text {above }}$ (Greco and Baldocchi, 1996):

$$
\begin{aligned}
F_{\mathrm{CO} 2}=\mathrm{NEE} & =P_{\text {gross }}+R_{\text {eco }} \\
& =P_{\text {gross }}+\left(R_{\text {soil }}+R_{\text {roots }}+R_{\text {above }}\right) .
\end{aligned}
$$

The quantities $F_{\mathrm{CO} 2}$, NEE, $R_{\text {eco }}$ and $P_{\text {gross }}$ indicate throughout this study fluxes of $\mathrm{CO}_{2}$ (and not of carbon) and have the unit $\mathrm{g} \mathrm{h}^{-1} \mathrm{~m}^{-2}$. This unit would equal in this context the unit $\mathrm{g} \mathrm{CO}_{2} \mathrm{~h}^{-1} \mathrm{~m}^{-2}$ which has often been used in other carbon flux publications. The ecosystem respiration is well known to depend on the temperature of the soils and the above-ground biomass. For the modelling of the ecosystem respiration, the time series of air temperature, radiative surface temperature, and soil temperature at various depths were studied with respect to their ability to describe the $\mathrm{CO}_{2}$ fluxes observed during dark periods ( $\mathrm{PAR}<20 \mu \mathrm{mol} \mathrm{m}^{-2} \mathrm{~s}^{-1}$ ), when photosynthesis was assumed to be negligible. The $\mathrm{CO}_{2}$ flux data and temperature data was fitted using the exponential function

$R_{\mathrm{eco}}=p_{1} e^{p_{2} T_{x}}$,

where $T_{x}$ is air, surface or soil temperature, and $p_{1}$ and $p_{2}$ are the fit parameters. The best fit $\left(R^{2}=0.79, N=611\right)$ was achieved when the radiative ground surface temperature $T_{\text {sur }}$ was used as independent variable (Fig. 6). Consequently, the relationship

$$
R_{\text {eco }}=0.0666 \mathrm{~g} \mathrm{~m}^{-2} \mathrm{~h}^{-1} \exp \left(0.0785^{\circ} \mathrm{C}^{-1} T_{\text {sur }}\right)
$$

was used for the estimation of the ecosystem respiration. The resulting model for night time $R_{\text {eco }}$ was extrapolated for the estimation of $R_{\text {eco }}$ during daytime. It was assumed that $R_{\text {above }}$ is of similar magnitude during day and night for the investigated tundra canopy. This simplification has been followed successfully by many other studies of carbon exchange of northern wetlands (Alm et al., 1997; Lloyd, 2001a; Harazono et al., 2003). Because there were no dark nights during the campaign in 2004, the model relies on 2003 data only. Ecosystem respiration in 2004 was modelled using the 2003 model, which showed to produce reasonable results. 


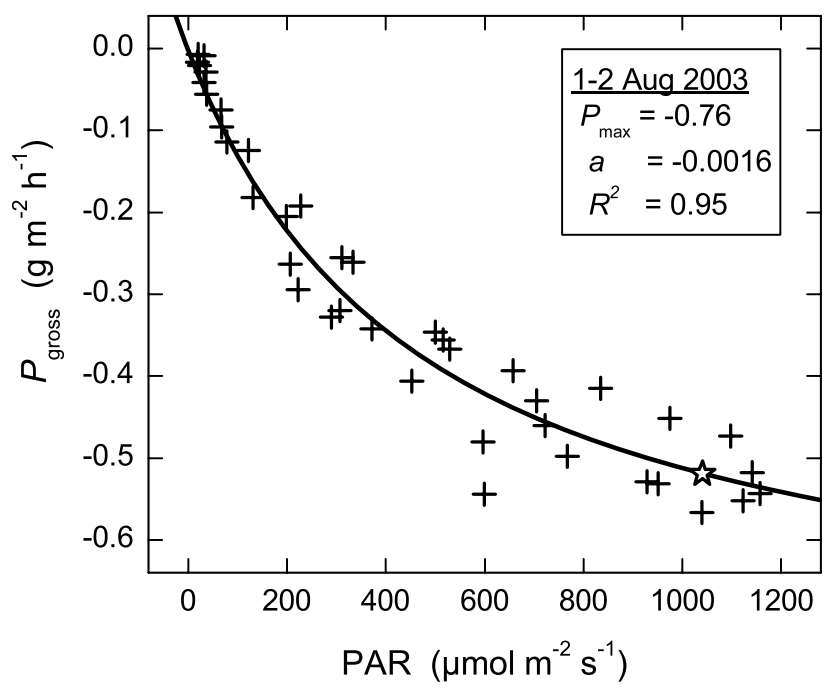

Fig. 3. Example for the relationship between gross photosynthesis $P_{\text {gross }}$ and photosynthetically active radiation PAR during the period 1-2 August 2003. Data points are hourly calculated $P_{\text {gross }}$. The white star indicates the point where the canopy quantum efficiency (the slope of the light response curve) is reduced to $10 \%$ of its initial value, i.e. where $P_{\mathrm{n}-\text { sat }}$ is reached. Photosynthesis rates are given as $\mathrm{CO}_{2}$ fluxes.

The gross photosynthesis $P_{\text {gross }}$ was calculated as the difference of measured $\mathrm{CO}_{2}$ flux and modelled ecosystem respiration

$P_{\text {gross }}=F_{\mathrm{CO} 2}-R_{\text {eco }}$.

For the modelling of $P_{\text {gross }}$, the time series was split into consecutive periods of two days in 2003 and three days in 2004 and fitted to PAR data using the rectangular hyperbola function

$P_{\text {gross }}=\frac{P_{\max } a \text { PAR }}{P_{\max }+a \text { PAR }}$.

The fit parameters $a$ and $P_{\max }$ are the initial canopy quantum efficiency (initial slope of the $P_{\text {gross }}-$ PAR curve at PAR=0) and the canopy photosynthetic potential (hypothetical maximum of $P_{\text {gross }}$ as PAR approaches infinity), respectively. A relatively short period of two to three days was chosen to reflect the rapid changes of the tundra vegetation, temperature and cloudiness conditions which influence the light response curve.

As $P_{\max }$ represents the theoretical photosynthesis rate at infinite PAR, it does not represent $P_{\text {gross }}$ in optimal radiation conditions within the actual PAR range (Laurila et al., 2001). For evaluating the light saturation over the season, the value $\mathrm{PAR}_{\mathrm{n}-\mathrm{sat}}$ is defined in this study as the PAR value where the canopy quantum efficiency is reduced to $10 \%$ of the initial canopy quantum efficiency $a$. PAR $_{\mathrm{n}-\text { sat }}$ was calculated as:

$\mathrm{PAR}_{\mathrm{n}-\mathrm{sat}} \approx 2.16 \frac{P_{\max }}{a}$.
Examples of the modelling of $P_{\text {gross }}$ and values of $\mathrm{PAR}_{\mathrm{n}-\mathrm{sat}}$ are given in Fig. 3.

The NEE time series were gap-filled by combining the empirical models for $R_{\text {eco }}$ and $P_{\text {gross }}$.

\section{Results}

\subsection{Meteorological conditions}

In 2003, measurements started on 19 July during the final phase of the polar day and lasted until 21 October, when the sun rose for only seven hours above the horizon (Fig. 4). Generally, the year 2003 was characterized by comparatively high temperatures; the average temperatures of July $\left(11^{\circ} \mathrm{C}\right)$ and September $\left(3^{\circ} \mathrm{C}\right)$ were $4 \mathrm{~K}$ and $2 \mathrm{~K}$ higher than the longterm averages. The months July, August, and September experienced extended periods of high air temperatures which were caused by advection of warm air from the Siberian mainland. At $168 \mathrm{~mm}$, the precipitation (rain) during the measurement period was exceptionally high. A large part of the rainfall was recorded during one week at the end of July (94 $\mathrm{mm}$ in six days). The precipitation pattern was reflected by the water table levels: Maximum water table heights were observed with $8 \mathrm{~cm}$ above soil surface in the polygon centre and $8 \mathrm{~cm}$ below the soil surface at the polygon rim on 25 July, when the strongest rainfall event occurred. Afterwards, the water table heights decreased gradually and reached their minimum at the end of September with $0 \mathrm{~cm}$ above soil surface in the centre and $13 \mathrm{~cm}$ below the soil surface at the rim. The volumetric water content in the top soil $(5 \mathrm{~cm}$ depth) in the centre and at the rim of the polygon was on average 97\% (saturation: 98\%) and 30\% (saturation: $47 \%$ ) during the period of unfrozen soils. During the course of the measurement campaign, the thaw depth increased from $28 \mathrm{~cm}$ to a maximum of $48 \mathrm{~cm}$ on 12 September. The soil temperatures followed the variations of the air temperature; however, the fluctuations were damped and phase-lagged dependent on depth below the soil surface and the position within the micro-relief. A strong temperature gradient existed in the unfrozen soil layer during the summer. Due to the relatively high temperatures in September, freezing of the soils from the top began late at around 29 September. At the end of the campaign on 21 October, the top soil layers were frozen, but underneath the frozen layer, unfrozen soil zones of several decimetres depth persisted. A snow cover built up starting 9 October. At the end of the campaign, the snow cover reached a thickness of about $15-25 \mathrm{~cm}$ in the polygon centres and just a few centimetres at the rims.

In 2004, the entire campaign was conducted under polar day conditions (Fig. 4). The year 2004 was characterized by a very cold winter, comparatively low temperatures during spring, and a late start of the growing season. The average temperatures of April $\left(-20^{\circ} \mathrm{C}\right)$, May $\left(-8^{\circ} \mathrm{C}\right)$ and June $\left(1^{\circ} \mathrm{C}\right)$ were $2 \mathrm{~K}, 1 \mathrm{~K}$ and $1 \mathrm{~K}$ lower compared to the long-term 




Fig. 4. Meteorological and soil data during the measurements campaigns 2003 and 2004. (A) air temperature at $2 \mathrm{~m}$ height, (B) daily sum of rainfall, (C) height of water table above soil surface at the centre (squares) and the rim (triangles) of a polygon, depth of frozen ground table (circles), and snow height (line without symbol), (D) soil volumetric water content at $5 \mathrm{~cm}$ depth at the centre (black) and the rim (grey) of a polygon, (E) soil temperature at the polygon centre at depths of $1 \mathrm{~cm}$ (black line), $10 \mathrm{~cm}$ (grey line), $20 \mathrm{~cm}$ (dotted line), and $30 \mathrm{~cm}($ dashed line).

means. At the beginning of the measurement campaign, the ground around the eddy tower was completely covered with snow and the soil temperatures were below $-10^{\circ} \mathrm{C}$ throughout the soil profile. The snow height was about $40 \mathrm{~cm}$ in the polygon centre and about $8 \mathrm{~cm}$ at the polygon rim. Before snow melt, sublimation of snow occurred throughout and snow-free patches appeared at the polygon rims on 29 May. However, frequent snowfall and snow drift kept the area size of the snow free patches small. The snow melt started on 8 June. The snow height decreased rapidly, and the polygon rims were largely free of snow after two days. Snow melt in the polygon centres continued until 18 June. The soils started to thaw around 13 June. The highest temperature in the upper soil layers was measured on 9 July, when the thaw depth was about $20 \mathrm{~cm}$. The thaw depth increased nearly linearly and reached a value of $26 \mathrm{~cm}$ at the end of the campaign. The to- tal rainfall up to 21 July was $60 \mathrm{~mm}$. A large part of the rain fell on 8-9 July. The water table was highest during snow melt (15 June) with $12 \mathrm{~cm}$ and $0 \mathrm{~cm}$ above the soil surface in the centre and at the rim of the polygon, respectively. Afterwards, the water table fell quickly, but due to the strong rainfall events of 8-9 July stayed close below or above the soil surface in the polygon centre until the end of the campaign. After thawing of the top $10 \mathrm{~cm}$ of the soils, the volumetric liquid water content in the top soil layer was on average $97 \%$ and $31 \%$ at the polygon centre and rim, respectively.

The average wind speed during the observation periods in 2003 and 2004 was $4.7 \mathrm{~m} \mathrm{~s}^{-1}$. Very light winds occurred seldom with wind speeds $<1 \mathrm{~m} \mathrm{~s}^{-1}$ observed less then $2 \%$ of the observation time. During the campaign 2003, there was no single predominant wind direction, however, wind directions east-northeast, south, and south-west occurred more 


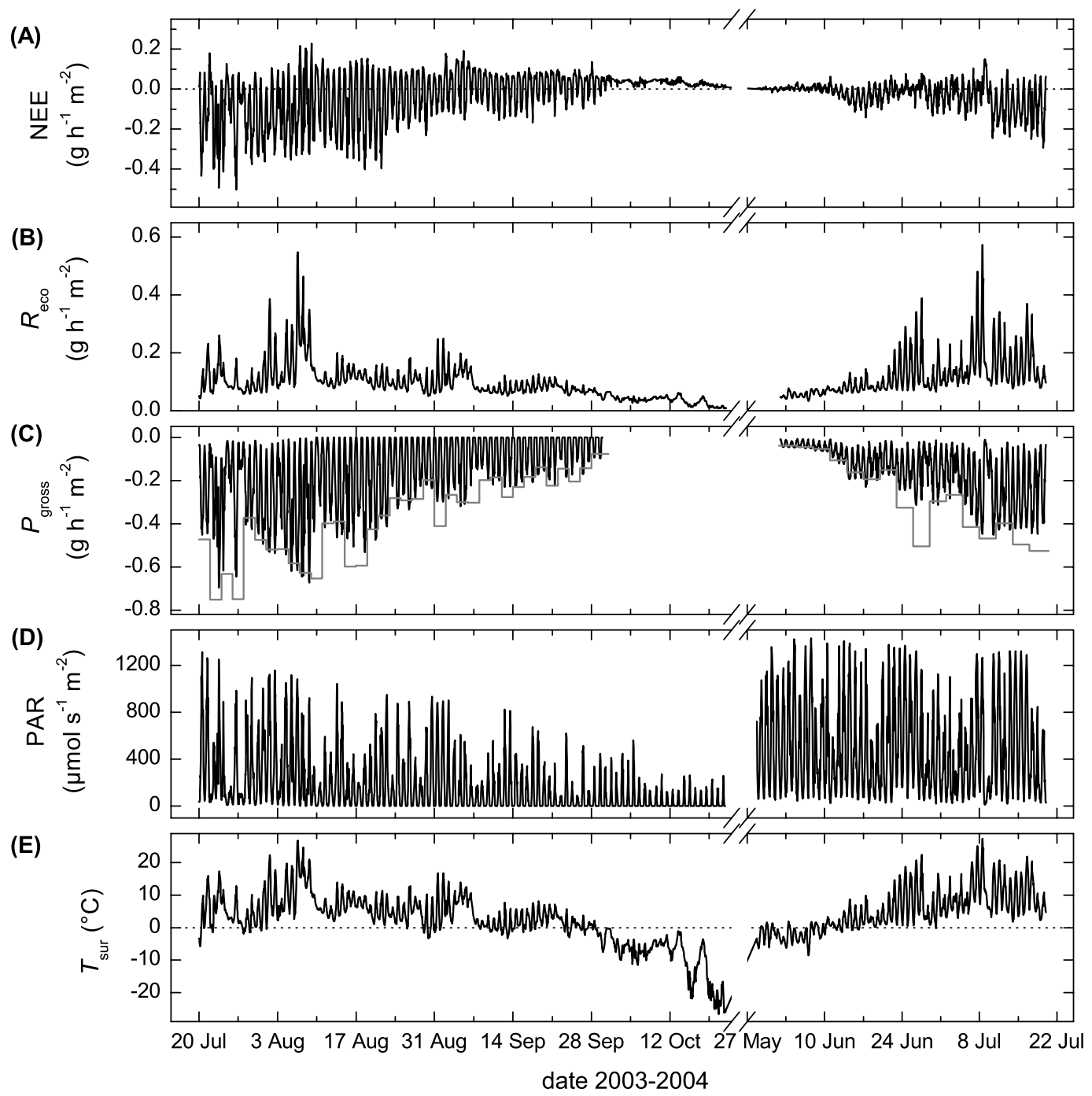

Fig. 5. $\mathrm{CO}_{2}$ budget components and meteorological controls in 2003 and 2004. (A) NEE measured by the eddy covariance method, (B) modelled ecosystem respiration $R_{\mathrm{eco}},(\mathrm{C})$ modelled gross photosynthesis $P_{\text {gross }}$ (black) and gross photosynthesis near light saturation $P_{\mathrm{n}-\text { sat }}$ (grey), (D) photosynthetically active radiation PAR; (E) surface radiative temperature $T_{\text {sur. }}$ NEE, $P_{\text {gross }}$ and $R_{\text {eco }}$ are given as CO fluxes.

frequently than other directions (data not shown). During the campaign 2004, there was a clear dominance of easterly winds (about $23 \%$ of the measurement period, data not shown), followed by winds from north-westerly directions. Wind directions not acceptable for flux calculations due to disturbance by the generator $\left(230^{\circ}-270^{\circ}\right)$ occurred $13.5 \%$ and $5.6 \%$ of the observation time in 2003 and 2004, respectively.

\subsection{Carbon dioxide fluxes}

During most of the measurement campaign 2003, NEE oscillated regularly between net uptake of $\mathrm{CO}_{2}$ during daytime and net $\mathrm{CO}_{2}$ release during night (Fig. 5). Between midJuly and mid-August, the amplitude of the diurnal oscillation was greatest, and daytime $\mathrm{CO}_{2}$ uptake dominated. Af- terwards, the amplitude decreased, and the $\mathrm{CO}_{2}$ release during night time gained more importance relative to the daytime $\mathrm{CO}_{2}$ uptake. After 29 September, uptake of $\mathrm{CO}_{2}$ ceased and NEE was continuously positive. At the end of the campaign at 21 October, $\mathrm{CO}_{2}$ release was still substantial with about $0.013 \mathrm{~g} \mathrm{~h}^{-1} \mathrm{~m}^{-2}$. The NEE time series was markedly affected by the synoptical weather pattern. For instance, during the strong rainfall on 25 July 2003 daytime $\mathrm{CO}_{2}$ uptake reached only $-0.17 \mathrm{~g} \mathrm{~h}^{-1} \mathrm{~m}^{-2}$ whereas it rose to more than $-0.50 \mathrm{~g} \mathrm{~h}^{-1} \mathrm{~m}^{-2}$ on the partly cloudy 26 July. Also, advection events of warm air from the south were clearly visible as shifts to higher nightly $\mathrm{CO}_{2}$ release, e.g. during 4-8 August and 2-7 September 2003.

The modelled ecosystem respiration ranged between $0.01 \mathrm{~g} \mathrm{~h}^{-1} \mathrm{~m}^{-2}$ and $0.55 \mathrm{~g} \mathrm{~h}^{-1} \mathrm{~m}^{-2}$ during the campaign 
2003. The largest $R_{\text {eco }}$ values and its largest diurnal amplitude were encountered in the first week of August, when the surface temperature was at its maximum during a pronounced event of advection of warm air from the south. The mean $R_{\text {eco }}$ during 4-8 August was $0.23 \mathrm{~g} \mathrm{~h}^{-1} \mathrm{~m}^{-2}$. Afterwards, $R_{\text {eco }}$ decreased; it averaged to $0.11 \mathrm{~g} \mathrm{~h}^{-1} \mathrm{~m}^{-2}$ during the second half of August, to $0.09 \mathrm{~g} \mathrm{~h}^{-1} \mathrm{~m}^{-2}$ during September and to $0.03 \mathrm{~g} \mathrm{~h}^{-1} \mathrm{~m}^{-2}$ during October.

The modelled gross photosynthesis ranged between zero and $-0.70 \mathrm{~g} \mathrm{~h}^{-1} \mathrm{~m}^{-2}$ during the campaign 2003. Following the daily trend of PAR, the amplitude of the diurnal oscillation of $P_{\text {gross }}$ was large. From the beginning of measurements until about 10 August, photosynthesis took place for $24 \mathrm{~h}$ per day, however, with only small absolute values during the night hours. The largest values of $P_{\text {gross }}$ were observed from mid-July to the first week of August. The mean $P_{\text {gross }}$ during this period was $-0.26 \mathrm{~g} \mathrm{~h}^{-1} \mathrm{~m}^{-2}$. Afterwards, the $P_{\text {gross }}$ decreased; it averaged to $-0.17 \mathrm{~g} \mathrm{~h}^{-1} \mathrm{~m}^{-2}$ during the second half of August, and to $-0.07 \mathrm{~g} \mathrm{~h}^{-1} \mathrm{~m}^{-2}$ during September. During October, $P_{\text {gross }}$ was zero. During the midday maxima of PAR, $P_{\text {gross }}$ frequently reached $P_{\mathrm{n}-\text { sat }}$, indicating that photosynthesis was limited by the saturation of the photosynthetically active tissue of the tundra canopy. Only on very cloudy days, midday $P_{\text {gross }}$ was limited by irradiation.

The pattern of the NEE time series of the campaign 2004 (Fig. 5) reflects the drastic changes of the physical conditions and the developmental stages of organisms during this period. Already at the last days of May, when the first snowfree patches appeared at some polygon rims, a weak diurnal oscillation of NEE between night time $\mathrm{CO}_{2}$ emission and daytime $\mathrm{CO}_{2}$ uptake was observed. NEE was around $+0.003 \mathrm{~g} \mathrm{~h}^{-1} \mathrm{~m}^{-2}$ during the night of 28/29 May and about $-0.002 \mathrm{~g} \mathrm{~h}^{-1} \mathrm{~m}^{-2}$ during midday of 29 May. The amplitude of this oscillation increased slowly during the first week of June. During the snow melt (8-18 June), the uptake of $\mathrm{CO}_{2}$ increased strongly and clearly dominated the NEE pattern. Afterwards, the midday peak values of $\mathrm{CO}_{2}$ uptake fluctuated substantially on the meso-scale but increased in general with NEE reaching a maximum of about $-0.25 \mathrm{~g} \mathrm{~h}^{-1} \mathrm{~m}^{-2}$ on 19 July. The night time $\mathrm{CO}_{2}$ emissions varied between $0.02 \mathrm{~g} \mathrm{~h}^{-1} \mathrm{~m}^{-2}$ and $0.15 \mathrm{~g} \mathrm{~h}^{-1} \mathrm{~m}^{-2}$ (mean $0.06 \mathrm{~g} \mathrm{~h}^{-1} \mathrm{~m}^{-2}$ ) and showed no clear trend.

Ecosystem respiration and gross photosynthesis were modelled beginning 2 June. Before this date, the models did not appropriately reflect the small-scale dynamics of the $\mathrm{CO}_{2}$ fluxes. During the period 2-20 June, the temperature of the top soil layers did not exceed $0^{\circ} \mathrm{C}$ and $R_{\text {eco }}$ was low with little diurnal variation. Afterwards, $R_{\text {eco }}$ increased strongly but also strongly depended on the synoptical weather pattern. The maximum of $R_{\text {eco }}$ was modelled for 8 July $\left(0.57 \mathrm{~g} \mathrm{~h}^{-1} \mathrm{~m}^{-2}\right)$, when air, surface and soils temperatures were high during the advection of warm air from the South. $R_{\text {eco }}$ was markedly lower during the advection of cold air from the North (e.g. 28 June-5 July). $R_{\text {eco }}$ averaged to
$0.05 \mathrm{~g} \mathrm{~h}^{-1} \mathrm{~m}^{-2}$ and $0.12 \mathrm{~g} \mathrm{~h}^{-1} \mathrm{~m}^{-2}$ during the first and second half of June, respectively, and to $0.16 \mathrm{~g} \mathrm{~h}^{-1} \mathrm{~m}^{-2}$ during July.

Before the beginning of snow melt on 8 June, gross photosynthesis was low with midday peak values of about $-0.05 \mathrm{~g} \mathrm{~h}^{-1} \mathrm{~m}^{-2}$. During this period, only few snow-free patches existed at some polygon rims. During the period of the snow melt (8-18 June), when more and more vegetation was released from the snow cover, $P_{\text {gross }}$ increased strongly to midday peak values of $-0.2 \mathrm{~g} \mathrm{~h}^{-1} \mathrm{~m}^{-2}$. During the snowfree period, $P_{\text {gross }}$ increased further and reached midday peak values around $-0.4 \mathrm{~g} \mathrm{~h}^{-1} \mathrm{~m}^{-2}$ in July. More distinctly than in 2003 , the photosynthesis was limited by the canopy photosynthetic potential. Especially in the first phase of the campaign, $P_{\text {gross }}$ frequently exceeded $P_{\mathrm{n} \text {-sat }}$ showing a high degree of light saturation of the canopy. With the development of the plants and increasing temperatures towards the end of June, $P_{\mathrm{n}-\text { sat }}$ increased so that the limitation of $P_{\text {gross }}$ by the canopy photosynthetic potential lost importance.

\subsection{The regulation of respiration and photosynthesis}

The study of the relationship between ecosystem respiration $R_{\text {eco }}$ and various temperatures revealed a close exponential relationship between $R_{\text {eco }}$ and the air temperature at $0.5 \mathrm{~m}$ above ground as well as the radiative ground surface temperature (Fig. 6a, b). However, the relationships between $R_{\text {eco }}$ and the soil temperatures at $1 \mathrm{~cm}$ depth at a polygon rim and centre site were less clear (Fig. 6c, d). The low performance of the exponential fits of $R_{\text {eco }}$ and soil temperature data was primarily caused by the different trends of the data series during the refreeze of soils (Figs. 4 and 5). During this time, due to the release of large amounts of latent heat, the soil temperatures remained for a long time at $0^{\circ} \mathrm{C}$ ("zero curtain effect"), whereas $R_{\text {eco }}$ decreased steadily.

The characteristic parameters of the tundra canopy photosynthetic activity as derived by the fit of $P_{\text {gross }}$ and PAR data using Eq. (7) are displayed for the synthetic measurement period 2004/2003 in Fig. 7. The canopy photosynthetic potential $P_{\max }$ generally followed the seasonal progression of the air temperature, reflecting the combined effect of the phenological development of the vegetation and the positive forcing of photosynthesis by temperature. When the first snow-free patches at the polygon rims appeared at the end of May, $P_{\max }$ was low but detectable with $-0.07 \mathrm{~g} \mathrm{~h}^{-1} \mathrm{~m}^{-2}$. After 8 June, when the daily average air temperature rose above $0^{\circ} \mathrm{C}$ and the snow melt started, $P_{\max }$ increased steadily until mid-July. The period of maximum $P_{\max }$ lasted approximately three to four weeks from mid-July to the first week of August with $P_{\max }$ values around $-0.8 \mathrm{~g} \mathrm{~h}^{-1} \mathrm{~m}^{-2}$ (range $-0.5 \mathrm{~g} \mathrm{~h}^{-1} \mathrm{~m}^{-2}-1.1 \mathrm{~g} \mathrm{~h}^{-1} \mathrm{~m}^{-2}$ ). This period indicates the mature phase of vegetation. As senescence started during August, $P_{\max }$ decreased at a high rate, later in September the decrease continued at lower rates. $P_{\max }$ decreased to zero at the end of September, when the daily average air 

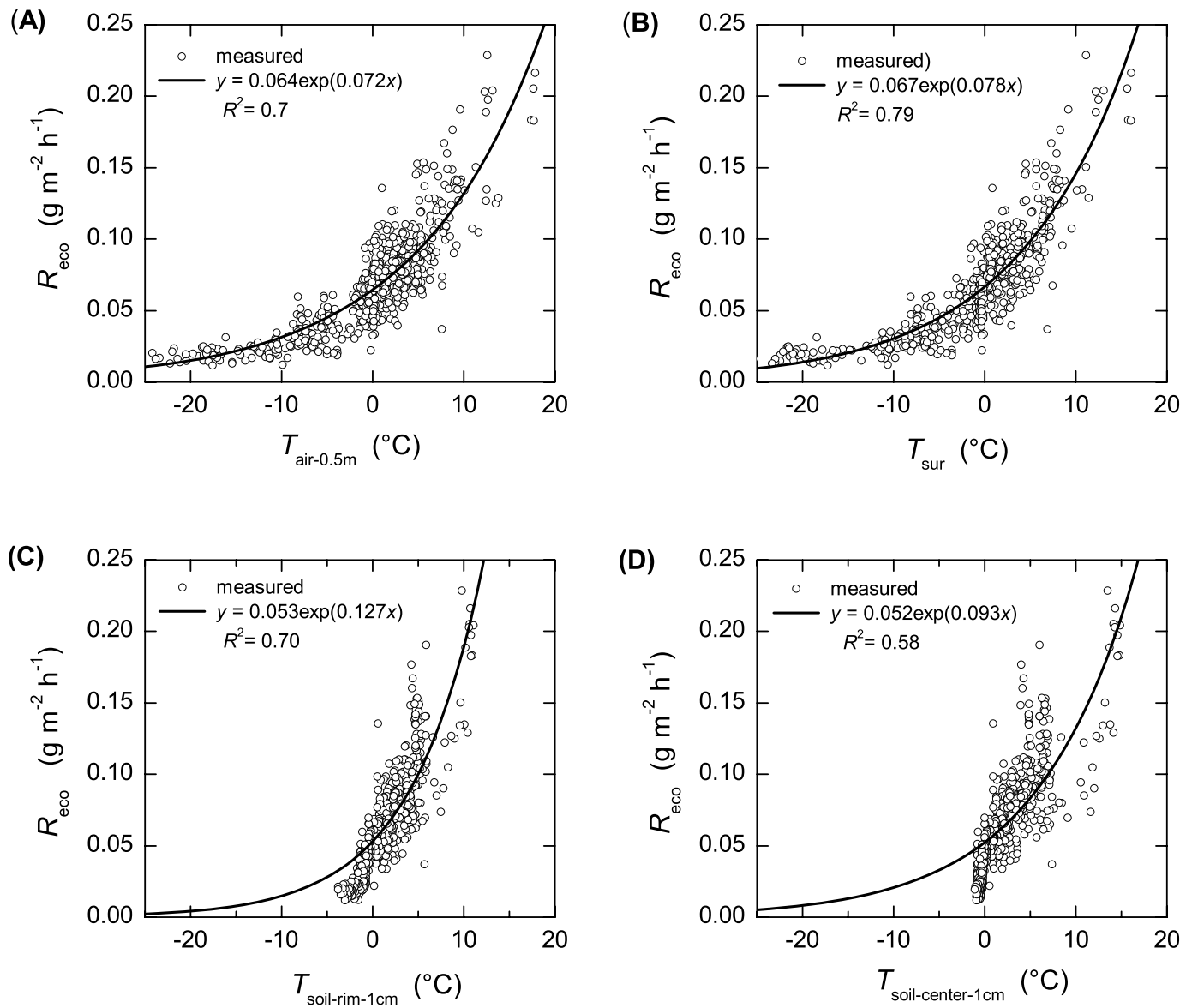

Fig. 6. Relationship between ecosystem respiration and (A) air temperature at $0.5 \mathrm{~m}$ height $T_{\text {air }-0.5 \mathrm{~m}}$, (B) surface radiative temperature $T_{\text {sur }}$, (C) soil temperature at a polygon rim at $1 \mathrm{~cm}$ depth $T_{\text {soil-rim-1 }}$, and (D) soil temperature at a polygon centre at $1 \mathrm{~cm}$ depth

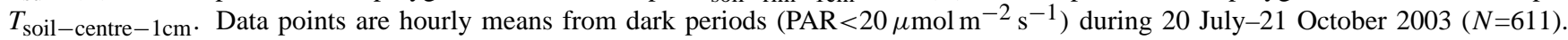
The data was fitted with exponential functions of the form given by Eq. (4). $R_{\text {eco }}$ is given as $\mathrm{CO}_{2}$ flux.

temperature fell below zero. The substantial scatter of $P_{\max }$ around the general trend especially during midsummer was at least partly related to the precipitation pattern and subsequent moisture changes in the top soils and the moss layer. Particularly high $P_{\max }$ values were observed during the periods of heavy rain at the end of July.

The initial canopy quantum efficiency $a$ increased similarly as $P_{\max }$, starting at the appearance of the first snow-free patches and leading to the mature phase of the vegetation, but peaked delayed compared to $P_{\max }$ during the second to third week of August. During autumn, $a$ decreased but still showed strong variations.

\subsection{Seasonal and annual $\mathrm{CO}_{2}$ balance}

The daily integrated components of the $\mathrm{CO}_{2}$ budget, $R_{\text {eco }}$, $P_{\text {gross }}$ and NEE are shown for the synthetic measurement period 29 May-21 October 2004/2003 in Fig. 8. At the beginning of June, $R_{\text {eco }}$ and $P_{\text {gross }}$ were low and of similar magnitude, and hence resulted in very low daily NEE. From 7
June to 9 July, the daily NEE alternated between net $\mathrm{CO}_{2}$ uptake and net $\mathrm{CO}_{2}$ release. This was related to the synoptic weather conditions and the dynamics of the underlying biological and soil-physical processes, i.e. the vegetation development and the thawing of the permafrost soils. From 10 July to 31 August, daily NEE was continuously negative and averaged to $-2.1 \mathrm{~g} \mathrm{~d}^{-1} \mathrm{~m}^{-2}$. The daily $\mathrm{CO}_{2}$ uptake reached a maximum of $-4.6 \mathrm{~g} \mathrm{~d}^{-1} \mathrm{~m}^{-2}$ at the end of July. After the beginning of September, daily NEE was positive on most days except during the cold period 10-15 September. From midSeptember to mid-October, the daily $\mathrm{CO}_{2}$ release was on average $0.7 \mathrm{~g} \mathrm{~d}^{-1} \mathrm{~m}^{-2}$; it decreased to the end of the campaign to about $0.3 \mathrm{~g} \mathrm{~d}^{-1} \mathrm{~m}^{-2}$.

The sums of $P_{\text {gross }}, R_{\text {eco }}$ and NEE over the whole measurement campaign amounted to $-432 \mathrm{~g} \mathrm{~m}^{-2},+344 \mathrm{~g} \mathrm{~m}^{-2}$ and $-90 \mathrm{~g} \mathrm{~m}^{-2}$, respectively. From 11 June to 31 August, the polygonal tundra was a net $\mathrm{CO}_{2}$ sink. During this period, $P_{\text {gross }}, R_{\text {eco }}$ and NEE summed to $-375 \mathrm{~g} \mathrm{~m}^{-2},+251 \mathrm{~g} \mathrm{~m}^{-2}$ and $-124 \mathrm{~g} \mathrm{~m}^{-2}$, respectively. From the beginning of 


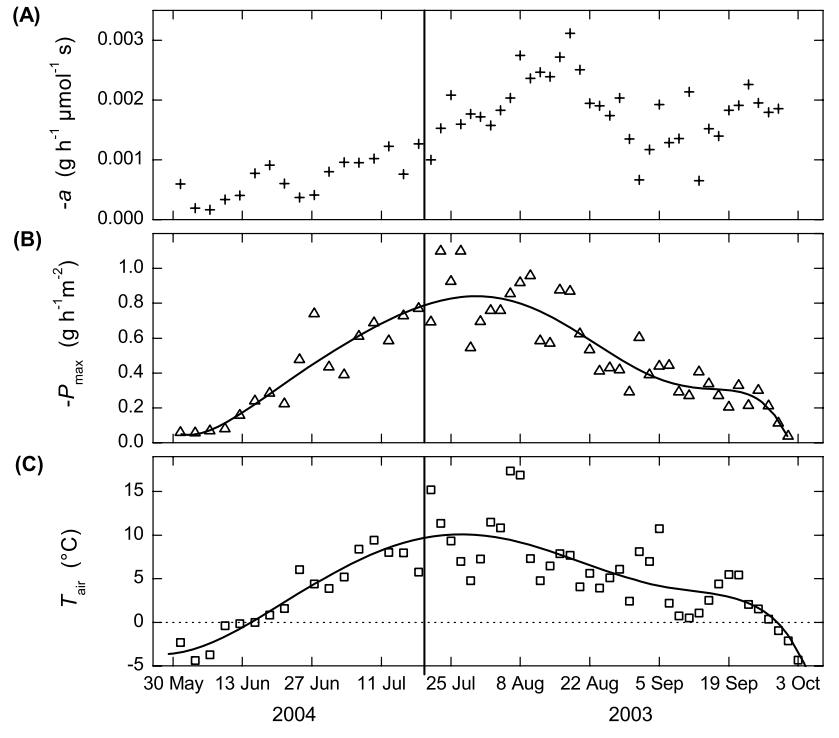

Fig. 7. Characteristic parameters of the tundra canopy photosynthetic activity as derived by the fit of $P_{\text {gross }}$ and PAR data using Eq. (7). (A) initial canopy quantum efficiency $a$, (B) canopy photosynthetic potential $P_{\max }$. (C) average air temperature $T_{\text {air }}$. Data points were calculated over two-day periods in 2003 and three-day periods in 2004. Black lines are polynomial fits. The time series of data were arranged so that they follow the seasonal course. Photosynthesis rates are calculated as a $\mathrm{CO}_{2}$ fluxes.

September, the polygonal tundra was a substantial $\mathrm{CO}_{2}$ source.

An estimate of the annual $\mathrm{CO}_{2}$ budget was calculated by combining the gap-filled NEE time series of 2003 and 2004 with estimated values of $R_{\text {eco }}$ for the winter and spring period 22 October 2003-28 May 2004 (220 days). The empirical models of $R_{\text {eco }}$ as a function of air, soil, and radiative ground surface temperature (Fig. 6) could not be used for the modelling of the wintertime $R_{\text {eco }}$. These models did not deliver sensible results when compared to measured $\mathrm{CO}_{2}$ fluxes during the first days of measurements in 2004. We assumed that air and radiative ground surface temperature did not reflect the temperature regime in the soil, where respiration took place, and that the models based on soil temperature data were biased by the presence of a still unfrozen soil layer in early winter. Hence, this study followed a more simple but conservative approach for estimating $R_{\text {eco }}$ during winter and spring (Fig. 9). The modelling period was divided in two periods which were separated by the date when the soils of the polygonal tundra were completely frozen (17 November 2003, derived from soil temperature records). During the period 17 November-28 May, $R_{\text {eco }}$ was set constant to the value $0.003 \mathrm{~g} \mathrm{~h}^{-1} \mathrm{~m}^{-2}$, which is the value observed during the night 28/29 May 2004, when the soils were still completely frozen. This value falls at the lower end of the range of mean winter $\mathrm{CO}_{2}$ fluxes reported by other authors from similar tundra sites (Fahnestock et al., 1998; Oechel et al.,

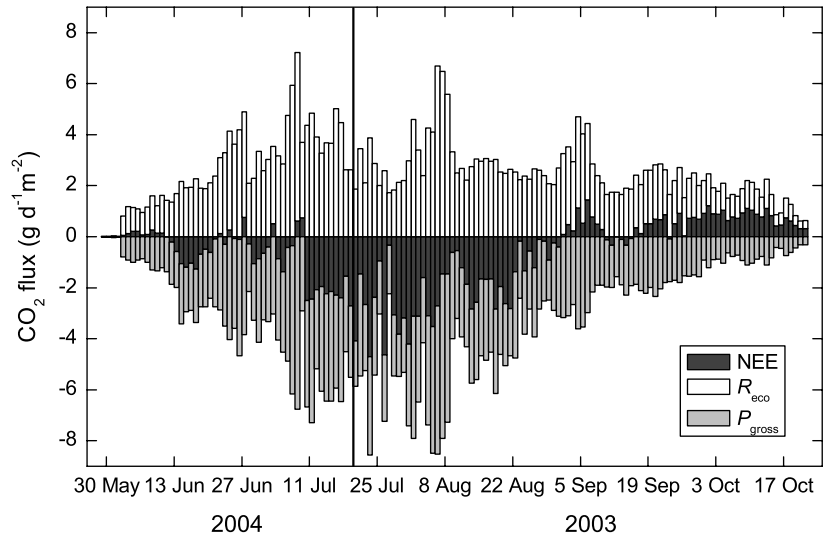

Fig. 8. Daily integrated $\mathrm{CO}_{2}$ budget components $\mathrm{NEE}, R_{\text {eco }}$ and $P_{\text {gross }}$ during the investigation period. The data are not stacked but NEE is overlaid on $R_{\text {eco }}$ and $P_{\text {gross. }}$. The time series of data were arranged so that they follow the seasonal course. NEE, $P_{\text {gross }}$ and $R$ eco are given as $\mathrm{CO}_{2}$ fluxes.

1997a; Panikov and Dedysh, 2000; Zimov et al., 1993; Table 1). The resulting estimate of NEE during this period (194 days) was $+14 \mathrm{~g} \mathrm{~m}^{-2}$. During the period 22 October17 November, $R_{\text {eco }}$ was estimated by linear interpolation between the value of $R_{\text {eco }}$ measured at 21 October 2003 $\left(0.013 \mathrm{~g} \mathrm{~h}^{-1} \mathrm{~m}^{-2}\right)$ and the value of $R_{\text {eco }}$ of the second period $\left(0.003 \mathrm{~g} \mathrm{~h}^{-1} \mathrm{~m}^{-2}\right)$. The resulting estimate of NEE during this period (26 days) was $+5 \mathrm{~g} \mathrm{~h}^{-1} \mathrm{~m}^{-2}$. Hence, the cumulative NEE for the one-year period 20 July 2003-19 July 2004 was $-71 \mathrm{~g} \mathrm{~m}^{-2}$, and the polygonal tundra of the study area was a $\mathrm{CO}_{2}$ sink during this period. Approximately $363 \mathrm{~g} \mathrm{CO}_{2} \mathrm{~m}^{-2}$ was respired by the plants and the soil organisms, which was about $84 \%$ of the annual $\mathrm{CO}_{2}$ assimilation by the vegetation of $432 \mathrm{~g} \mathrm{CO}_{2} \mathrm{~m}^{-2}$.

\section{Discussion}

\subsection{Gross photosynthesis}

\subsubsection{Comparison with other tundra sites}

The integrated value of $P_{\text {gross }}$ of the wet polygonal tundra in the Lena River Delta for the period June-August was $-383 \mathrm{~g} \mathrm{~m}^{-2}$. This value was low compared to $P_{\text {gross }}$ estimates for other arctic tundra sites. Estimates of $P_{\text {gross }}$ for the same seasonal period for wet sedge tundra and moist tussock tundra on the North Slope of Alaska were $-519 \mathrm{~g} \mathrm{~m}^{-2}$ and $-858 \mathrm{~g} \mathrm{~m}^{-2}$, respectively (Vourlites et al., 2000). The lower value observed in this study is partly related to later snow melt but also to generally lower $P_{\text {gross }}$ values during midsummer. The peak $P_{\text {gross }}$ value at the wet sedge tundra site described by Vourlites et al. (2000) was $-13.2 \mathrm{~g} \mathrm{~d}^{-1} \mathrm{~m}^{-2}$ whereas the peak value at the Lena River Delta was only $-8.6 \mathrm{~g} \mathrm{~d}^{-1} \mathrm{~m}^{-2}$. At mixed moist to wet tundra on the 


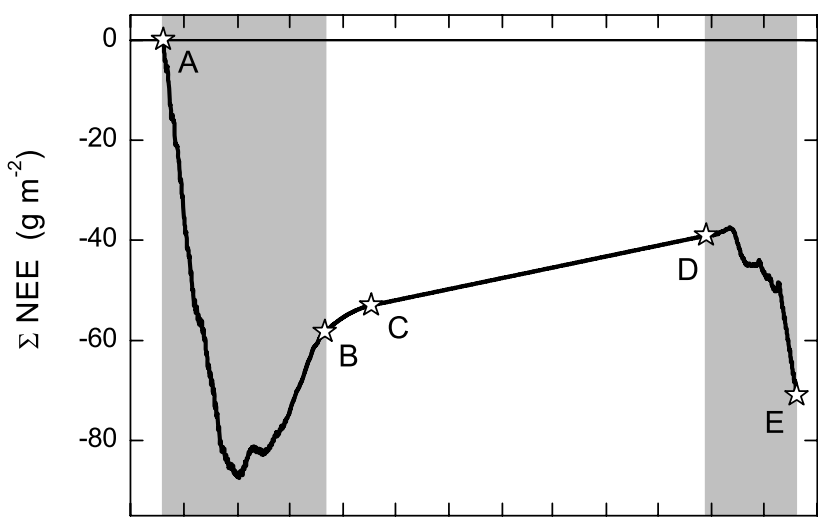

Jul Aug Sep Oct Nov Dec Jan Feb Mar Apr May Jun Jul

date 2003-2004

Fig. 9. Cumulative net ecosystem exchange $\Sigma$ NEE from July 2003 to July 2004 . The periods of the micrometeorological measurements are highlighted by the grey background. The stars indicate: $\mathrm{A}=$ start of measurements $2003, \mathrm{~B}=$ start of modelling period with linearly decreasing $R_{\mathrm{eco}}, \mathrm{C}=$ start of modelling period with constant $R_{\text {eco }}$ of $0.003 \mathrm{~g} \mathrm{~h}^{-1} \mathrm{~m}^{-2}, \mathrm{D}=$ start of measurements 2004 , E=end of measurements 2004. $\Sigma \mathrm{NEE}$ is given as a cumulative $\mathrm{CO}_{2}$ flux.

Chukotskiy Peninsula, peak $P_{\text {gross }}$ was even greater with $-14.7 \mathrm{~g} \mathrm{~d}^{-1} \mathrm{~m}^{-2}$ (Zamolodchikov et al., 2003).

Harazono et al. (2003) reported total annual values of $P_{\text {gross }}$ in the range of $-788 \mathrm{~g} \mathrm{~m}^{-2}$ to $-539 \mathrm{~g} \mathrm{~m}^{-2}$ for a flooded wet sedge tundra site at Barrow, Alaska. The annual $P_{\text {gross }}$ at the Lena River Delta was substantially lower with $-432 \mathrm{~g} \mathrm{~m}^{-2}$. Zamolodchikov and Karelin (2001) estimated the average annual $P_{\text {gross }}$ for the whole Russian tundra area to be $-759 \mathrm{~g} \mathrm{~m}^{-2}$. The maximum seasonal canopy photosynthetic potential $P_{\max }$ at the Lena River Delta of $-1.1 \mathrm{~g} \mathrm{~h}^{-1} \mathrm{~m}^{-2}$ was very near to the average tundra $P_{\max }$ of $-1.04 \mathrm{~g} \mathrm{~h}^{-1} \mathrm{~m}^{-2}$ calculated by Buchmann and Schulze (1999). However, the maximum of $P_{\max }$ at an arctic fen on Greenland was substantially higher with $-1.6 \mathrm{~g} \mathrm{~h}^{-1} \mathrm{~m}^{-2}$ (Laurila et al., 2001; Nordstroem et al., 2001).

Consequently, the wet polygonal tundra in the Lena River Delta has to be considered as a tundra ecosystem with comparatively low gross primary productivity. This low productivity is related to the low coverage of vascular plants in the investigated wet polygonal tundra (maximum summer leaf coverage about 0.3 ). Mosses, which have an high leaf coverage of about 0.95 at the study site, have a much lower photosynthetic capacity than vascular plants. Furthermore, the production of photosynthetically active tissue of vascular plants is considered to be strongly constrained by a low nutrient availability at the polygonal tundra of the Lena River Delta. Tundra plants avoid nutrient limitation of photosynthesis by limiting the amount of photosynthetic tissue within the support capabilities of the amount of nutrients available (Tieszen et al., 1980). However, they were found to be al- ways on the borderline of being nutrient-limited (Ulrich and Gersper, 1978).

Most tundra soils are characterized by a low nutrient availability due to the cold and often waterlogged soil conditions, which slow down microbial and soil fauna activity and consequently decomposition and mineralization of organic matter (Chapin et al., 1980a; Gersper et al., 1980; Shaver et al., 1998; Johnson et al., 2000; Hobbie et al., 2002). Furthermore, the soils of the polygonal tundra at the investigation site have to be considered as extremely poor, even when compared to other tundra soils. Water-logging is prominent due to the flat macro-relief and the development of low-centred polygons. The growing season is short, and the soils are extremely cold also during summer due to the very cold permafrost of Northern Siberia. The parent material of the soils consists mainly of fluvial, nutrient-poor sands of the Holocene river terrace. Moreover, the Holocene river terrace on which the polygonal tundra has formed is not flooded regularly anymore during the spring flood, so that no fresh nutrients are transported to the soils.

The soils at wet sedge tundra sites for which much higher gross photosynthesis was reported in the literature compared to this study (see above) are considered less nutrient-limited than the soils of the investigation site of this study as they were situated at the bottom of mountain valleys (Vourlites et al., 2000; Laurila et al., 2001) or on fine-grained marine sediments at coastal tundra (Brown et al., 1980; Harazono et al., 2003). On moist tundra sites, e.g. tussock tundra or shrub tundra, $P_{\text {gross }}$ appears to be generally larger than at wet sedge tundra sites due to more favourable conditions for the growth of vascular plants (Vourlites and Oechel, 1999; Vourlites et al., 2000; McFadden et al., 2003; Zamolodchikov et al., 2003).

\subsubsection{Control by irradiation}

Arctic tundra ecosystems have often been described as lightlimited ecological systems (Tieszen et al., 1980). However, the results of this study showed that during the day $P_{\text {gross }}$ was often limited by saturation of the photosynthetic apparatus of the canopy. Although the canopy never reached full light saturation, the quantum efficiency declined substantially during midday high PAR intensities. A similar response of $P_{\text {gross }}$ to the diurnal PAR trend was described for wet sedge and tussock tundra in Alaska by Vourlites and Oechel (1997, 1999). The leaves of vascular tundra plant species approach light saturation at PAR values of $1300-1600 \mu \mathrm{mol} \mathrm{s}^{-1} \mathrm{~m}^{-2}$ (Tieszen et al., 1980), a value that was not reached at the investigation site during the growing season. However, arctic mosses tend to reach light saturation already at PAR values of around $450 \mu \mathrm{mol} \mathrm{s}^{-1} \mathrm{~m}^{-2}$, which is exceeded on average from 07:00 to 19:00 during June and July at the Lena River Delta. The observed limitation of $P_{\text {gross }}$ by the amount of photosynthetically active tissue in the tundra canopy under the current climate support the notion that enhanced plant 
Table 1. Comparison of cumulative net ecosystem $\mathrm{CO}_{2}$ exchange $\Sigma$ NEE reported by other investigators and by this study. Note that the comparison periods differ depending on the availability of data. $\Sigma$ NEE was calculated by integrating the $\mathrm{CO}_{2}$ fluxes over the comparison period specified.

\begin{tabular}{|c|c|c|c|c|c|}
\hline Reference & Location & Tundra type & $\begin{array}{l}\text { Comparison } \\
\text { period }\end{array}$ & $\begin{array}{r}\Sigma \mathrm{NEE} \\
\left(\mathrm{g} \mathrm{m}^{-2}\right)\end{array}$ & $\begin{array}{r}\Sigma \text { NEE this } \\
\text { study } \\
\left(\mathrm{g} \mathrm{m}^{-2}\right)\end{array}$ \\
\hline $\begin{array}{l}\text { Nordstroem et al. } \\
\text { (2001) }\end{array}$ & $\begin{array}{l}\text { Zackenberg, Greenland } \\
74^{\circ} \mathrm{N}, 20^{\circ} \mathrm{W}\end{array}$ & $\begin{array}{l}\text { wet fen and } \\
\text { grassland }\end{array}$ & Jun...Aug 1997 & -120 & -119 \\
\hline $\begin{array}{l}\text { Groendahl et al. } \\
\text { (2007) }\end{array}$ & $\begin{array}{l}\text { Zackenberg, Greenland } \\
74^{\circ} \mathrm{N}, 20^{\circ} \mathrm{W}\end{array}$ & $\begin{array}{l}\text { high Arctic } \\
\text { heath }\end{array}$ & $\begin{array}{l}\text { DOY } 159 \ldots 238 \\
1997 \\
2000 \\
2001 \\
2002 \\
2003\end{array}$ & $\begin{array}{r}-5 \\
-69 \\
-30 \\
-36 \\
-85\end{array}$ & -117 \\
\hline Lloyd (2001b) & $\begin{array}{l}\text { Ny-Ålesund, Svalbard } \\
80^{\circ} \mathrm{N}, 12^{\circ} \mathrm{E}\end{array}$ & $\begin{array}{l}\text { subpolar desert, } \\
\text { mosses }\end{array}$ & $\begin{array}{l}\text { June...Aug 1995; } \\
1996\end{array}$ & $\begin{array}{l}-4 \\
+5\end{array}$ & -119 \\
\hline $\begin{array}{l}\text { Oechel et al. } \\
\text { (1993) }\end{array}$ & $\begin{array}{l}\text { Prudhoe Bay, Alaska } \\
70^{\circ} \mathrm{N}, 148^{\circ} \mathrm{W}\end{array}$ & wet sedge & $\begin{array}{l}\text { June...Sep (125 d) } \\
1990\end{array}$ & 16 & -116 \\
\hline $\begin{array}{l}\text { Vourlites and } \\
\text { Oechel (1997) }\end{array}$ & $\begin{array}{l}\text { U-Pad, Alaska } \\
70^{\circ} \mathrm{N}, 149^{\circ} \mathrm{W}\end{array}$ & $\begin{array}{l}\text { moist to wet } \\
\text { herbaceous }\end{array}$ & $\begin{array}{l}\text { June...Aug 1994; } \\
1995\end{array}$ & $\begin{array}{l}-67 \\
-48\end{array}$ & -119 \\
\hline $\begin{array}{l}\text { Vourlites and } \\
\text { Oechel (1999) }\end{array}$ & $\begin{array}{l}\text { Happy Valley, Alaska } \\
69^{\circ} \mathrm{N}, 149^{\circ} \mathrm{W}\end{array}$ & moist tussock & June...Aug 1995 & -203 & -119 \\
\hline $\begin{array}{l}\text { Vourlites et al. } \\
(2000)\end{array}$ & $\begin{array}{l}\text { Happey Valley, Alaska } \\
69^{\circ} \mathrm{N}, 149^{\circ} \mathrm{W}\end{array}$ & wet sedge & June...Aug 1995 & -281 & -119 \\
\hline $\begin{array}{l}\text { Harazono et al. } \\
(2003)\end{array}$ & $\begin{array}{l}\text { Barrow, Alaska } \\
71^{\circ} \mathrm{N} ; 156^{\circ} \mathrm{W}\end{array}$ & wet sedge & $\begin{array}{l}\text { May...Sep 1999; } \\
2000\end{array}$ & $\begin{array}{l}-593 \\
-384\end{array}$ & -104 \\
\hline $\begin{array}{l}\text { Zamolodchikov and } \\
\text { Karelin (2001) }\end{array}$ & whole Russian tundra & all types & $\begin{array}{l}\text { June...Sep }(117 \mathrm{~d}) \\
\text { model }\end{array}$ & -103 & -121 \\
\hline $\begin{array}{l}\text { Zamolodchikov et } \\
\text { al. (2003) }\end{array}$ & $\begin{array}{l}\text { Lavrentiya, Siberia } \\
65^{\circ} \mathrm{N}, 171^{\circ} \mathrm{W}\end{array}$ & $\begin{array}{l}\text { mixed: moist to } \\
\text { wet }\end{array}$ & $\begin{array}{l}\text { mid-July... } \\
\text { mid-Oct., } 2000\end{array}$ & -37.4 & -47 \\
\hline Corradi et al. (2005) & $\begin{array}{l}\text { Cherskii, Siberia } \\
69^{\circ} \mathrm{N}, 162^{\circ} \mathrm{E}\end{array}$ & $\begin{array}{l}\text { moist to wet } \\
\text { tussock }\end{array}$ & July...Aug 2002 & -100 & -112 \\
\hline Corradi et al. (2005) & $\begin{array}{l}\text { Cherskii, Siberia } \\
69^{\circ} \mathrm{N}, 162^{\circ} \mathrm{E}\end{array}$ & $\begin{array}{l}\text { moist to wet } \\
\text { tussock }\end{array}$ & $\begin{array}{l}\text { Sep...June } \\
\text { 2002/2003 }\end{array}$ & 62 & 40 \\
\hline Zimov et al. (1993) & $\begin{array}{l}\text { Cherskii, Siberia } \\
69^{\circ} \mathrm{N}, 162^{\circ} \mathrm{E}\end{array}$ & $\begin{array}{l}\text { moist shrub and } \\
\text { grass }\end{array}$ & $\begin{array}{l}\text { Dec...Feb } \\
1989 / 1990\end{array}$ & 51 & 7 \\
\hline Oechel et al. (1997a) & Alaska & wet sedge & $\begin{array}{l}\text { Oct...May } \\
1993 / 1994\end{array}$ & 73 & 35 \\
\hline $\begin{array}{l}\text { Fahnestock et al. } \\
\text { (1998) }\end{array}$ & $\begin{array}{l}\text { Prudhoe Bay, Alaska } \\
70^{\circ} \mathrm{N}, 148^{\circ} \mathrm{W}\end{array}$ & wet sedge & Feb...May 1996 & 1.84 & 9 \\
\hline $\begin{array}{l}\text { Panikov and Dedysh } \\
(2000)\end{array}$ & $\begin{array}{l}\text { Bakshar Bog, Siberia } \\
57^{\circ} \mathrm{N}, 82^{\circ} \mathrm{E}\end{array}$ & ombrotrophic bog & Feb 1995 & 7 & 2 \\
\hline
\end{tabular}


growth under a warming climate may increase $P_{\text {gross }}$ and thus $\mathrm{CO}_{2}$ uptake by arctic canopies provided that nutrient availability will increase in parallel (Shaver et al., 1992, 1998; Oechel et al., 2000; Hobbie et al., 2002).

\subsubsection{Control by phenological development}

The seasonal variation of $P_{\text {gross }}$ was mainly controlled by the phenological development of the canopy and the production of photosynthetically active leave area, which in turn was related to the general temperature progression over the growing season. Photosynthesis started directly when the first snow-free patches appeared on the polygon rims at the end of May. Most of this early photosynthesis was probably accomplished by mosses, whose photosynthetically active tissues can overwinter and start to assimilate $\mathrm{CO}_{2}$ as soon as it is freed from the snow cover (Oechel, 1976). Also the vascular plants start to grow and photosynthesize within one day of snow melt (Tieszen et al., 1980). However, their photosynthetic rate is at first very low since their photosynthetically active tissues are not maintained over winter and have to be produced newly. From the start of photosynthesis, $P_{\text {gross }}$ increased until the mature stage of the vascular plants was reached at mid-July. Senescence of the vascular plants started after the first week of August and $P_{\max }$ decreased as proteins and other materials were hydrolyzed and mobilized. In contrast, the mosses showed no senescence and continued to photosynthesize until the air temperature dropped below zero (Fig. 7). The shoulders of the seasonal progression curve of $P_{\max }$ (28 May-10 June and 11-29 September) are considered to indicate periods of only moss photosynthesis. By interpolating between these dates, the contribution of moss photosynthesis to the total $P_{\text {gross }}$ during the photosynthetically active period was estimated to be approximately $40 \%$. Miller et al. (1980) found by harvesting methods that mosses contributed about $30 \%$ to the gross primary production of a similar wet tundra canopy.

The non-synchronous seasonal trends of $P_{\max }$ and $a$ is probably related to the different seasonal development of vascular plants and mosses. The coefficients of the light response model of $P_{\text {gross }}$ have a firm physiological basis: $P_{\max }$ is indicative of the development and capacity of the $\mathrm{CO}_{2}$ fixation apparatus, such as the amount and activity of the carboxylation enzyme Rubisco, whereas $a$ is determined by the leave chlorophyll content and photosynthetically active leaf area (Vourlites and Oechel, 1999). The moss layer can be considered to have a large photosynthetically leave area (high a) but a markedly lower content of Rubisco than vascular plants (low $P_{\max }$ ) (Miller et al., 1980). Thus, senescence of the vascular plants affected $P_{\max }$ stronger and earlier than $a$.

\subsubsection{Control by temperature}

Temperature is generally a major control factor on $P_{\text {gross }}$. While the light reactions of photosynthesis are insensitive to temperature, the dark reactions are highly sensitive to temperature since the activity of Rubisco has a distinct temperature optimum. However, the temperature optima of the photosynthesis of arctic plants are broad. The photosynthesis optima for vascular plants and bryophytes were found to be $10-15^{\circ} \mathrm{C}$ and $10-19^{\circ} \mathrm{C}$, respectively (Oechel, 1976; Tieszen et al., 1980). Even at $0^{\circ} \mathrm{C}$, photosynthetic activity of Arctic plant species is substantial. The lower limit of photosynthesis was shown to be about $-4^{\circ} \mathrm{C}$ (Tieszen et al., 1980).

Despite the adaptation of Arctic vegetation to the low temperatures in the Arctic, plant growth and consequently $P_{\text {gross }}$ is severely constrained by the low temperatures and the short growing season. The timing of the snow melt has a great influence on the length of the growing season and the annual $P_{\text {gross }}$. Variations in growing season length probably accounted for much of the large interannual variation in $P_{\text {gross }}$ observed by several studies in the Arctic (Vourlites and Oechel, 1997; Lloyd, 2001b; Harazono et al., 2003). Atmospheric warming may prolong the summer period free of frost and snow and permit a longer growing season, increased plant growth and higher $\mathrm{CO}_{2}$ assimilation of both vascular plants and mosses (Sveinbjörnsson and Sonesson, 1997; Oechel et al., 1998). When projecting future changes of $\mathrm{CO}_{2}$ assimilation due to climate change, it has to be kept in mind that phenological events such as bud break, culm elongation and flower development in spring and summer as well as senescence and bud dormancy initiation in autumn are controlled by a complex suite of environmental and plant-internal variables including not only temperature but also photoperiod or species internal periodicity (Heide, 1990, 1997, 2005; Oberbauer et al., 1998; Keller and Körner, 2003). In the Arctic, however, the timing of snowmelt and soil thaw has to be considered as the key factor in determining the start of the growing season (Pop et al., 2000; Chapin et al., 2005). The photoperiod would only limit significantly the plant development in spring if the snowmelt would be drastically earlier (for example April) because the timing of snowmelt in the Arctic under the actual climate occurs during all-day-light conditions near the summer solstice. On the other hand, the triggering of the end of the growing season is less well understood and probably the result of several interacting factors (Oberbauer et al., 1998; Van Wijk et al., 2003). In the long-term, an extension of the growing season will favour species which are able to adapt to and benefit from a longer growing season enhancing thus vegetation community changes in the Arctic (Chapin et al., 2005).

\subsubsection{Control by water availability}

Water availability is considered to be of minor importance for the regulation of whole canopy gross photosynthesis at the wet polygonal tundra. As neither a depression of $P_{\text {gross }}$ nor a decrease of evapotranspiration at midday by stomatal regulation was observed, the vascular plants were considered to not experience appreciable water stress. However, 
the meso-scale variations around the general trend of $P_{\max }$ (Fig. 7) could in part be attributed to the response of mosses to water availability. Mosses are very sensitive to changes in available water since they cannot control their tissue water content (Miller et al., 1980). In the periods between precipitation or dew events, the mosses at the moist polygon rims desiccated, particularly during warm and dry weather (Lloyd, 2001a, b). The desiccation of mosses led to a decrease of the moss photosynthetic potential which consequently also reduced the whole canopy photosynthetic potential $P_{\max }$. During events of rain, the tissue water content of the mosses was replenished and moss photosynthetic potential resumed quickly (Sveinbjörnsson and Sonesson, 1997). These processes were clearly observable from the middle of July to the beginning of August, when periods of high precipitation alternated with dry and warm periods and the calculated $P_{\max }$ fluctuated substantially on the scale of several days. An alternative or complementing explanation for the increased $P_{\max }$ during rainy periods could be that during cloudy weather the diffuse radiation is higher, which is more effective in feeding photosynthesis than direct sunlight (Roderick et al., 2001; Stanhill and Cohen, 2001; Gu et al., 2003; Rocha et al., 2004).

\subsection{Ecosystem respiration}

\subsubsection{Comparison with other tundra sites}

The average $R_{\text {eco }}$ observed at the polygonal tundra of the Lena River Delta during summer and the autumnal period of refreezing was comparatively low. It amounted to $60 \%$ of average $R_{\text {eco }}$ observed at a moist to wet tussock tundra at the Kolyma River lowlands in North-East Siberia (Corradi et al., 2005), to $60 \%$ of $R_{\text {eco }}$ at moist to wet tundra on the Chukotskiy Peninsula (Zamolodchikov et al., 2003), to 47$54 \%$ of $R_{\text {eco }}$ at a high arctic fen (Soegaard and Nordstroem, 1999; Nordstroem et al., 2001), to 38-44\% of $R_{\text {eco }}$ at tussock tundra at an Alaskan mountain valley (Vourlites and Oechel, 1999; Vourlites et al., 2000) and to $50 \%$ of the average $R_{\text {eco }}$ modelled for the whole Russian tundra area (Zamolodchikov and Karelin, 2001). On the other hand, $R_{\text {eco }}$ observed in this study was equal to $R_{\text {eco }}$ at wet sedge tundra at an Alaskan mountain valley (Vourlites et al., 2000), about two times higher than $R_{\text {eco }}$ reported for flooded wet sedge tundra at the coastal plain of Alaska (Harazono et al., 2003) and about 2.3 times higher than $R_{\text {eco }}$ at an high-arctic semi-desert at Svalbard (Lloyd, 2001a).

Major controls on $R_{\text {eco }}$ are temperature, soil moisture, water table position, soil redox conditions, nutrient availability, vegetation type and litter quality (Hobbie et al., 2002; Ping et al., 1997; Christensen et al., 1998; Zamolodchikov and Karelin, 2001). Most of these control factors are not favourable for a high $R_{\text {eco }}$ at the wet polygonal tundra of the Lena River Delta: Soil temperatures are low due to the very cold permafrost in the region. Widespread water-logged con- ditions cause anaerobic soil conditions, and nutrient availability is poor as described before. Furthermore, the vegetation is characterized by a low coverage of vascular plants and a high coverage of mosses, which are known to produce extremely recalcitrant litter and even bactericidal substances in their tissues (Zimov et al., 1993; Hobbie et al., 2002).

The comparison of values of $R_{\mathrm{eco}}$ and $P_{\text {gross }}$ given by other studies for tundra ecosystems reveals that $R_{\text {eco }}$ is generally higher in ecosystems with higher $P_{\text {gross }}$, with the exception of permanently flooded tundra types which showed relatively low $R_{\text {eco }}$ and high $P_{\text {gross }}$ (Harazono et al., 2003). More $\mathrm{CO}_{2}$ is assimilated by the vegetation in tussock tundra (Vourlites and Oechel, 1999; Vourlites et al., 2000; Corradi et al., 2005) than in wet sedge tundra (Vourlites and Oechel, 1997; this study), but also more $\mathrm{CO}_{2}$ is released by the respiratory processes. At arctic semi-desert sites, the rates of both $R_{\text {eco }}$ and $P_{\text {gross }}$ are much lower compared to all real tundra sites (Lloyd 2001a, b). Regional comparison studies on Greenland and arctic Alaska found that $R_{\text {eco }}$ increased with the leaf area index LAI. This was explained by a combination of greater leaf maintenance respiration increasing with LAI and increased soil respiration due to better litter quality and larger root biomass at higher productivity sites (Soegaard et al., 2000; McFadden et al., 2003).

\subsubsection{Control by temperature}

Most of the variation of $R_{\text {eco }}$ during summer and autumn could be well modelled by an exponential function between $R_{\text {eco }}$ and the surface temperature $\left(R^{2}=0.79\right.$ for the 2003 campaign). The good performance of the $R_{\text {eco }}$ model based on surface temperature can be explained by the importance of the above-ground plant respiration. Although most of the biomass in wet sedge-dominated tundra ecosystems (80$88 \%$ ) is belowground in roots and rhizomes of the grasses and sedges (Billings et al., 1977; Chapin et al., 1980b), 30 $46 \%$ of summer $R_{\text {eco }}$ in grass and sedge tundra was found to originate from above-ground sources (Peterson and Billings, 1975; Nordstroem et al., 2001; Zamolodchikov and Karelin, 2001). This high respiration in the relatively small aboveground biomass reflects the intense biological activity inside the arctic plants during the short growing season. Within only three months, the vascular tundra plants have to develop their complete photosynthetically active tissue, to flower and to senesce. All these processes imply intense allocation of nutrients and carbohydrates, which is powered by autotrophic respiration. Furthermore, soil and root respiration was shown to be most prominent in the uppermost centimetres of tundra soils (Billings et al., 1977; Sommerkorn, 1998). However, heterotrophic respiration can not be assumed to have a significant contribution to the above-ground respiration, because there is not much litter above the ground surface, which would mean on the dense moss layer or between the living moss stems. An additional explanation for the poor fits of $R_{\mathrm{eco}}$ to the soil temperatures compared to the 
surface temperature is that the soil respiration probably declined gradually during the refreeze period in response to the continuously low temperatures while the temperatures itself stayed stable due to the "zero curtain" effect.

\subsubsection{Seasonal progression of $R_{\text {eco }}$}

At the polygonal tundra of the Lena River Delta, $70 \%$ of the estimated annual $R_{\text {eco }}$ took place during the summer months June-August. This value is well within the range of $60-80 \%$ estimated by Coyne and Kelley (1975). However, also the autumn was found to be important for the dynamics of $R_{\text {eco }}$ at the investigation site. About $20 \%$ of the estimated annual $R_{\text {eco }}$ was achieved in September. During the freezing of the soils from October to mid-November, $R_{\text {eco }}$ amounted to $6 \%$ of the annual ecosystem respiration. The so-called "period of autumnal carbon emission" (Zamolodchikov and Karelin, 2001) is a common feature of high-latitude ecosystems and is one of the causes of the high atmospheric $\mathrm{CO}_{2}$ concentration during winter which was observed over northern Siberia (Fung et al., 1987; Zimov et al., 1993; Zamolodchikov and Karelin, 2001).

On the other hand, no pronounced period of $\mathrm{CO}_{2}$ net emission during spring snow melt was observed as reported for a range of tundra sites (Vourlites and Oechel, 1997; Soegaard et al., 2000; Vourlites et al., 2000; Nordstroem et al., 2001; Zamolodchikov and Karelin, 2001; Corradi et al., 2005). During the snow melt period 2004 , daily $R_{\text {eco }}$ exceeded $P_{\text {gross }}$ only slightly and for only a few days. Photosynthesis started directly when the first snow-free patches appeared and outweighed the low respiration. Similar early season trends of $\mathrm{CO}_{2}$ exchange were reported for tussock tundra and flooded sedge tundra in Alaska by Vourlites and Oechel (1999), and Harazono et al. (2003). It is suggested here that the reason for this pronounced difference in the seasonal $\mathrm{CO}_{2}$ progression may be related to the interannual variability of the timing of snow melt, which is thought to have a strong effect on the balance of early season $P_{\text {gross }}$ and $R_{\text {eco }}$ (Groendahl et al., 2007).

The approach for the estimation of $R_{\text {eco }}$ during winter and spring performed in this study resulted in a comparatively low value of winter and spring $R_{\text {eco }}$ of $4 \%$ of the annual $R_{\text {eco. }}$ It is well known that microbial (bacterial and fungal) respiration takes place also during much of the winter (Zimov et al., 1993; Oechel et al., 1997a; Fahnestock et al. 1998; Grogan et al. 2001). Microbial respiration continues even in soils cooled down to $-39^{\circ} \mathrm{C}$ (Flanagan and Bunnell, 1980; Michaelson and Ping, 2003; Panikov et al., 2006). Furthermore, $\mathrm{CO}_{2}$ which has been produced during autumn and trapped in the frozen ground can probably be released in winter via small cracks in the frozen ground. (Zimov et al., 1993; Oechel et al., 1997a). For instance, Corradi et al. (2005) reported substantial $R_{\text {eco }}$ of $0.65 \mathrm{~g} \mathrm{~d}^{-1} \mathrm{~m}^{-2}$ at wet tussock tundra at the Kolyma River lowlands in April, when the temperature in the top soil was $-13^{\circ} \mathrm{C}$ under a snow pack of
$60 \mathrm{~cm}$. Oechel et al. (1997a) also observed very high winter fluxes of $1.1 \mathrm{~g} \mathrm{~d}^{-1} \mathrm{~m}^{-2}$ and $0.29 \mathrm{~g} \mathrm{~d}^{-1} \mathrm{~m}^{-2}$ at Alaskan tussock and wet sedge tundra, respectively. Harazono et al. (2003) observed occasional large pulses of $\mathrm{CO}_{2}$ emission from a frozen and snow-covered flooded wet sedge tundra in Alaska during May, which they related to events of high wind speed causing snow saltation and the release of $\mathrm{CO}_{2}$ stored in the snow pack. In contrast, Fahnestock et al. (1998) observed much lower winter $R_{\text {eco }}$ values of $0.02 \mathrm{~g} \mathrm{~d}^{-1} \mathrm{~m}^{-2}$ at Alaskan wet sedge tundra. In this study $R_{\text {eco }}$ was measured as $0.072 \mathrm{~g} \mathrm{~d}^{-1} \mathrm{~m}^{-2}$ at the end of May. This value fell in between the $R_{\text {eco }}$ values reported by the previous studies and was assumed to be representative for $R_{\text {eco }}$ during the whole winter and spring period. It is thought that this estimation method neither underrated nor overrated $R_{\text {eco }}$ drastically, but the considerable uncertainty of estimates for the winter $R_{\mathrm{eco}}$ and consequently also of the annual $\mathrm{CO}_{2}$ budget should be kept in mind.

\subsection{Net ecosystem $\mathrm{CO}_{2}$ exchange}

The ecosystem of the wet polygonal tundra is characterized by a comparatively low intensity of carbon cycling. Both main $\mathrm{CO}_{2}$ exchange processes between the ecosystem and the atmosphere, the gross photosynthesis $P_{\text {gross }}$ and the ecosystem respiration $R_{\text {eco }}$, were low due to the environmental conditions at the site, which include climatic as well as pedogenetic factors. The net ecosystem exchange NEE depends on the balance of $\mathrm{CO}_{2}$ uptake by $P_{\text {gross }}$ and $\mathrm{CO}_{2}$ emission by $R_{\text {eco. }}$. Since the two opposed fluxes $P_{\text {gross }}$ and $R_{\text {eco }}$ are much larger than their balance NEE, small relative changes in $P_{\text {gross }}$ or $R_{\text {eco }}$ can cause large relative changes of NEE. The measurements presented in this study showed that the wet polygonal tundra of the Lena River Delta was a substantial net $\mathrm{CO}_{2}$ sink during the summer $\left(-119 \mathrm{~g} \mathrm{~m}^{-2}\right.$ during June-August). Also on the annual basis, the polygonal tundra was estimated to be a $\mathrm{CO}_{2} \operatorname{sink}\left(-71 \mathrm{~g} \mathrm{~m}^{-2}\right)$ because the $\mathrm{CO}_{2}$ efflux during autumn, winter and spring was assessed to be moderate ( $+48 \mathrm{~g} \mathrm{~m}^{-2}$ during September-May).

In Table 1, the cumulative NEE observed in this study is compared with NEE values reported from other tundra sites for different time periods. The cumulative $\mathrm{CO}_{2}$ uptake observed during summer at the polygonal tundra in the Lena River Delta was similar to values reported for a high-arctic fen in Greenland (Nordstroem et al., 2001), a moist to wet tussock tundra at the Kolyma River lowlands in North-East Siberia (Corradi et al., 2005) and a mixed moist and wet tundra at the Chukotskiy Peninsula (Zamolodchikov et al., 2003). The mean summer $\mathrm{CO}_{2}$ uptake for the whole Russian tundra area modelled by Zamolodchikov and Karelin (2001) was slightly lower than the value observed in this study. On the other hand, summer cumulative $\mathrm{CO}_{2}$ uptake was several times higher at wet sedge and tussock tundra sites at an Alaskan mountain valley (Vourlites and Oechel, 1999; Vourlites et al., 2000) and at wet sedge tundra at the Alaskan 
coastal plain (Harazono et al., 2003). However, cumulative summer $\mathrm{CO}_{2}$ uptake at a moist to wet polygonal tundra at the coastal plain of Alaska was only about half the value measured in this study (Vourlites and Oechel, 1997). The cumulative summer $\mathrm{CO}_{2}$ uptake at high-Arctic dry ecosystems was observed to be - though very variable over different years - substantially lower than at the studied polygonal tundra (Lloyd, 2001b; Groendahl et al., 2007). The estimated annual $\mathrm{CO}_{2}$ sink strength at the polygonal tundra of the Lena River Delta was equal to the sink strength of a higharctic fen at Greenland (Soegaard et al., 2000) and about half of the sink strength of wet tussock tundra at the Kolyma River lowlands (Corradi et al., 2005). On the other hand, it was about four times the average sink strength estimated for the whole Russian tundra area (Zamolodchikov and Karelin, 2001), which is due to a markedly higher estimate for $R_{\text {eco }}$, especially for the winter period by the latter authors. Given the observed high spatial variability of NEE between tundra ecosystems, generalised conclusions on the response of the biome tundra on climatic change appear questionable (Oechel et al., 1993, 2000).

The function of tundra ecosystems as $\mathrm{CO}_{2}$ sources or sinks was found to fluctuate considerably on the inter-annual and decadal scales in response to fluctuating meteorological conditions and changing climate (Groendahl et al, 2007; Oechel et al., 1993, 2000). The only eddy covariance study on NEE performed for more than two growing seasons in the Arctic demonstrated large inter-annual differences of summer $\mathrm{CO}_{2}$ net ecosystem exchange at a high-Arctic heath tundra ranging over more than one order of magnitude, i.e. from $-5 \mathrm{~g} \mathrm{~m}^{-2}$ to $-85 \mathrm{~g} \mathrm{~m}^{-2}$ (Groendahl et al., 2007). This shows that $\mathrm{CO}_{2}$ flux results from one or two years as given by most of the published work including this study can not be generalised easily to be valid on the multi-annual time scale which is most relevant for regional and global carbon budgets as well as climate change projections. Oechel et al. (1993) stated that Alaskan tussock and wet-sedge tundra ecosystems, which were strong $\mathrm{CO}_{2}$ sinks in the cool and wet 1970s (Coyne and Kelley, 1975; Chapin et al., 1980a), had changed to a pronounced net $\mathrm{CO}_{2}$ source during the mid-1980s and the early 1990s due to the acceleration of soil decomposition under a warming and drying climate. Even during the warm, photosynthetically active season (June-September), the examined tundra ecosystems were net $\mathrm{CO}_{2}$ sources. However, the same authors reported that between 1992 and 1996, in response to further warming and drying, net summer releases of $\mathrm{CO}_{2}$ to the atmosphere of both ecosystems declined, and they eventually became $\mathrm{CO}_{2}$ sinks again (Vourlites and Oechel, 1997; Oechel et al., 2000). The authors suggested that the return to $\mathrm{CO}_{2}$ sink activity of the tundra ecosystems was related to changes in nutrient cycling, physiological acclimation, and population and community reorganization which enhanced the gross primary productivity of the tundra vegetation (Shaver et al., 1998; Chapin et al., 1995, 2005; Sturm et al., 2001b). These findings underline the im- portance of long-term flux studies for the assessment of how Arctic ecosystems will respond to a changing climate and how this response will feed back to the climate system.

The carbon balance of the wet polygonal tundra is not complete with the study of $\mathrm{CO}_{2}$, because the polygonal tundra is also a source of methane $\left(\mathrm{CH}_{4}\right)$. Methane is an important radiatively active trace gas, second only to $\mathrm{CO}_{2}$ in its cumulative effect on the additional anthropogenic greenhouse effect. The global warming potential (GWP) of $\mathrm{CH}_{4}$ for a 100-year time horizon is about 25 times the GWP of $\mathrm{CO}_{2}$ (IPCC, 2007). During the micrometeorological campaigns 2003 and 2004 described in this study, also the ecosystem exchange of $\mathrm{CH}_{4}$ was measured by the eddy covariance method (Wille et al., 20072). The cumulative $\mathrm{CH}_{4}$ emission over the combined measurement periods 2003 and 2004 was calculated by Wille et al. to be $2.4 \mathrm{~g} \mathrm{~m}^{-2}$ which corresponds to a carbon $\left(\mathrm{C}-\mathrm{CH}_{4}\right)$ release of $1.8 \mathrm{~g} \mathrm{~m}^{-2}$. The cumulative $\mathrm{CO}_{2}$ ecosystem exchange NEE over the combined measurement periods of $-90 \mathrm{~g} \mathrm{~m}^{-2}$ calculated in this study corresponds to a carbon $\left(\mathrm{C}-\mathrm{CO}_{2}\right)$ uptake of $24.5 \mathrm{~g} \mathrm{~m}^{-2}$. Consequently, the $\mathrm{C}-\mathrm{CH}_{4}$ release was about $7 \%$ of the net $\mathrm{C}-\mathrm{CO}_{2}$ uptake over the combined measurement period 2003 and 2004 (end of May to middle of October). The annual cumulative C$\mathrm{CH}_{4}$ release of $2.25 \mathrm{~g} \mathrm{~m}^{-2}$ estimated by Wille et al. was $12 \%$ of the annual cumulative $\mathrm{C}-\mathrm{CO}_{2}$ uptake of $19.4 \mathrm{~g} \mathrm{~m}^{-2}$ estimated in this study. The ratio of the $\mathrm{CH}_{4}$ emission to the $\mathrm{CO}_{2}$ uptake was substantially lower at the studied Arctic polygonal tundra compared to other Siberian wetlands with higher $\mathrm{CH}_{4}$ emissions (Friborg et al., 2003; Corradi et al., 2005). The greenhouse gas balance expressed as mass flux of $\mathrm{CO}_{2}$ equivalents was calculated considering the 100-year GWP of $\mathrm{CH}_{4}$ of 25 (IPCC, 2007). It was around $-60 \mathrm{~g} \mathrm{~m}^{-2}$ (uptake) for the combined measurement periods (end of May to middle of October) and not significantly different from zero $\left(+4 \mathrm{~g} \mathrm{~m}^{-2}\right)$ for the annual estimates of $\mathrm{CO}_{2}$ and $\mathrm{CH}_{4}$ exchange. Further discussions on the greenhouse gas balance can be found in Wille et al. $(2007)^{2}$.

\section{Conclusions}

This study delivered a range of new results on the processes of the $\mathrm{CO}_{2}$ cycling at wet arctic tundra of Northern Siberia which are considered to be of concern not only for the Lena River Delta but also for the extensive area of the North Siberian lowland tundra as a whole. On the basis of the presented results and discussions, the following main conclusions are drawn:

The $\mathrm{CO}_{2}$ budget of the investigated tundra was determined by (1.) the polar and distinctly continental climate, (2.) the very cold and ice-rich permafrost which underlies the tundra of Northern Siberia, (3.) the wetland character of polygonal

\footnotetext{
${ }^{2}$ Wille, C., Kutzbach, L., and Pfeiffer, E.-M.: Methane emission from Siberian arctic polygonal tundra: Eddy covariance measurements and modeling, Glob. Change Biol., in review, 2007.
} 
tundra, (4.) the position at the interface between the Arctic Ocean and the Siberian mainland, (5.) the long duration of the snow coverage, (6.) the generally low nutrient status of the soils at the site, and (7.) a vegetation cover which is dominated by sedges and mosses.

The exchange fluxes of $\mathrm{CO}_{2}$ showed clear seasonal trends on which the diurnal oscillation and pronounced meso-scale variations were superimposed. The meso-scale variations were related to the synoptic weather conditions and strongly affected the exchange fluxes through changes of cloudiness, precipitation and pronounced changes of air temperature. Thus, the large-scale atmospheric circulation patterns, for example the phase of the Arctic Oscillation, have a strong influence on the function of the North-Siberian tundra as a sink or source of $\mathrm{CO}_{2}$.

The $\mathrm{CO}_{2}$ budget of the wet polygonal tundra was characterized by a generally low intensity of the main $\mathrm{CO}_{2}$ exchange processes between the ecosystem and the atmosphere, namely the gross photosynthesis $P_{\text {gross }}$ and the ecosystem respiration $R_{\text {eco }}$. Both processes were attenuated by the unfavourable environmental conditions at the site, which included climatic as well as pedogenetic factors.

The cumulative $P_{\text {gross }}$ amounted to $-432 \mathrm{~g} \mathrm{~m}^{-2}$ over the photosynthetically active period (June-September). The rather low $P_{\text {gross }}$ was related to the low coverage of vascular plants, mainly sedges, and a high coverage of mosses at the polygonal tundra. The contribution of moss photosynthesis to the annual $P_{\text {gross }}$ was estimated to be about $40 \%$. The gross primary productivity of the vegetation of the wet polygonal tundra was constrained by the low nutrient availability in the soils.

The diurnal response of $P_{\text {gross }}$ was mainly controlled by the irradiation. During midday the photosynthetic apparatus of the canopy was frequently near saturation and represented the limiting factor on $P_{\text {gross }}$. The seasonal progression of $P_{\text {gross }}$ was controlled by the combination of the phenological development of the vegetation and the general temperature progression over the summer. The phenological development of the plants was largely controlled by intrinsic factors. However, temperature was also a major control on $P_{\text {gross }}$ at the investigation site since photosynthesis took place for most of the time below its temperature optimum. On the other hand, water availability had only minor importance as control on $P_{\text {gross }}$ due to the wet soil conditions at polygonal tundra. Only when the mosses at the drier microsites of the polygon rim experienced water stress, $P_{\text {gross }}$ was reduced significantly.

The cumulative $R_{\text {eco }}$ amounted to $+327 \mathrm{~g} \mathrm{~m}^{-2}$ over the photosynthetically active period (June-September), which corresponded to $76 \%$ of the cumulative $P_{\text {gross }}$. However, $R_{\text {eco }}$ continued at substantial rates during autumn when photosynthesis had ceased and the soils were still largely unfrozen and to a lesser degree throughout the winter and spring. The significant $R_{\text {eco }}$ during autumn, winter and spring was a major but highly uncertain factor in the an- nual $\mathrm{CO}_{2}$ balance which should be addressed in future winter campaigns. The temporal variability of $R_{\text {eco }}$ during summer was best explained by the surface temperature and not by the soil temperature. This finding demonstrated the high and often overlooked importance of the autotrophic plant respiration within the $\mathrm{CO}_{2}$ balance. Indeed, the composition and productivity of the vegetation had to be considered as major controls on $R_{\text {eco }}$.

Under the observed meteorological conditions, the wet polygonal tundra of the Lena River Delta acted as a $\mathrm{CO}_{2}$ sink with a cumulative net ecosystem $\mathrm{CO}_{2}$ exchange NEE of $-119 \mathrm{~g} \mathrm{~m}^{-2}$ over the summer (June-August) and an estimated annual NEE of $-71 \mathrm{~g} \mathrm{~m}^{-2}$. A more complete carbon balance must include the release of $\mathrm{CH}_{4}$ from the ecosystem to the atmosphere. Since the carbon released as $\mathrm{CH}_{4}$ was observed to be about $7 \%$ of the carbon uptake as $\mathrm{CO}_{2}$ over the combined measurement period 2003 and 2004 and estimated to be about $12 \%$ of the carbon uptake as $\mathrm{CO}_{2}$ over the whole year (Wille et al., 2007²), this will still result in a clear carbon sink function of the investigated wet arctic tundra, both for the vegetation period and the whole year. However, considering the high global warming potential of $\mathrm{CH}_{4}$, the annual greenhouse gas balance of the investigated Siberian tundra can be estimated to be near-neutral.

Acknowledgements. We would like to thank the members of the joint Russian-German field expeditions LENA-ANABAR 2003 and LENA 2004, namely W. Schneider, G. Stoof, L. Heling, and U. Zimmermann, as well as our Russian partners D. Y. Bolshianov (Arctic and Antarctic Research Institute, St. Petersburg), M. N. Grigoriev (Permafrost Institute, Yakutsk), A. Y. Derevyagin (Moscow State University), D. V. Melnitschenko (Hydro Base Tiksi), A. Y. Gukov (Lena Delta Reserve) and their colleagues at the respective institutes.

Edited by: T. Laurila

\section{References}

Alm, J., Talanov, A., Saarnio, S., Silvola, J., Ikkonen, E., Aaltonen, H., Nykänen, H., and Martikainen, P. J.: Reconstruction of the carbon balance for microsites in a boreal oligotrophic pine fen, Finland, Oecologia, 110, 423-431, 1997.

Are, F. E. and Reimnitz, E.: An overview of the Lena River Delta setting: geology, tectonics, geomorphology, and hydrology, J. Coastal Res., 16(4), 1083-1093, 2000.

Aubinet, M., Grelle, A., Ibron, A., et al.: Estimates of the annual net carbon and water exchange of forests: the EUROFLUX methodology, Adv. Ecol. Res., 30, 113-175, 2000.

Beringer, J., Tapper, N. J., McHugh, I., Chapin III, F. S., Lynch, A. H., Serreze, M. C., and Slater, A.: Impact of Arctic treeline on synoptic climate, Geophys. Res. Lett., 28(22), 4247-4250, 2001.

Billings, W. D.: Carbon balance of Alaskan tundra and taiga ecosystems: past, present and future, Quaternary Sci. Rev., 6(2), 165177, 1987. 
Billings, W. D., Peterson, K. M., Shaver, G. R., and Trent, A. W.: Root growth, respiration, and carbon dioxide evolution in an arctic tundra soil, Arct. Alp. Res., 9(2), 129-137, 1977.

Bonan, G. B., Chapin III, F. S., and Thompson, S. L.: Boreal forest and tundra ecosystems as components of the climate system, Climatic Change, 29, 145-167, 1995.

Broecker, W. S.: Thermohaline circulation, the Achilles heel of our climate system: Will man-made $\mathrm{CO}_{2}$ upset the current balance?, Science, 278, 1582-1588, 1997.

Brown, J., Everett, K. R., Webber, P. J., MacLean Jr., S. F., and Murray, D. F.: The coastal tundra at Barrow, in: An Arctic Ecosystem: the Coastal Tundra at Barrow, Alaska, Dowden, edited by: Brown, J., Miller, P. C., Tieszen, L. L., et al., Hutchinson \& Ross Inc., Stroudsburg, USA, 1980.

Buchmann, N. and Schulze, E.-D.: Net $\mathrm{CO}_{2}$ and $\mathrm{H}_{2} \mathrm{O}$ fluxes of terrestrial ecosystems, Global Biogeochem. Cy., 13, 751-760, 1999.

Callaghan, T. V. and Jonasson, S.: Implications for changes in arctic plant biodiversity from environmental manipulation experiments, in: Arctic and Alpine Biodiversity: Patterns, Causes, and Ecosystem Consequences, edited by: Chapin III, F. S. and Körner, C. H., Springer-Verlag, Heidelberg, Germany, 1995.

Chapin III, F. S., Miller, P. C., Billings, W. D., and Coyne, P. I.: Carbon and nutrient budgets and their control in coastal tundra, in: An Arctic Ecosystem: the Coastal Tundra at Barrow, Alaska, Dowden, edited by: Brown, J., Miller, P. C., Tieszen, L. L., et al., Hutchinson \& Ross Inc., Stroudsburg, USA, 1980a.

Chapin III, F. S., Tieszen, L. L., Lewis, M. C., Miller, P. C., and McCown, B. H.: Control of tundra plant allocation patterns and growth, in: An Arctic Ecosystem: the Coastal Tundra at Barrow, Alaska, Dowden, edited by: Brown, J., Miller, P. C., Tieszen, L. L., et al., Hutchinson \& Ross Inc., Stroudsburg, USA, 1980b.

Chapin III, F. S., Jeffries, R. L., Reynolds, J. F., Shaver, G. R., and Svoboda, J.: Arctic Ecosystems in a Changing Climate: an Ecophysiological Perspective, Academic Press, San Diego, USA, 1992.

Chapin III, F. S., Shaver, G. R., Giblin, A. E., Nadelhoffer, K. G., and Laundre, J. A.: Responses of Arctic tundra to experimental and observed changes in climate, Ecology, 76, 694-711, 1995.

Chapin III, F. S., McFadden, J. P., and Hobbie, S. E.: The role of arctic vegetation in ecosystem and global processes, in: Ecology of Arctic Environments, edited by: Woodin, S. J. and Marquiss, M., Blackwell Science, Oxford, UK, 1997.

Chapin III, F. S., Sturm, M., Serreze, M. C., et al.: Role of Land-Surface Changes in Arctic Summer Warming, Science, 310(5748), 657-660, 2005.

Christensen, T.: Methane emission from arctic tundra, Biogeochemistry, 21, 117-139, 1993.

Christensen, T. R., Jonasson, S., Michelsen, A., Callaghan, T. V., and Havström, M.: Environmental controls on soil respiration in the Eurasian and Greenlandic Area, J. Geophys. Res., 103(D22), 29 015-29 021, 1998.

Coyne, P. I. and Kelley, J. J.: $\mathrm{CO}_{2}$ exchange over the Alaskan arctic tundra: meteorological assessment by an aerodynamic method, J. Appl. Ecol., 12, 587-611, 1975.

Corradi, C., Kolle, O., Walter, K., Zimov, S. A., and Schulze, E.-D.: Carbon dioxide and methane exchange of a north-east Siberian tussock tundra, Global Change Biol., 11, 1-16, 2005.

Eugster, W., Rouse, W. R., Pielke Sr., R. A., et al.: Land-atmosphere energy exchange in Arctic tundra and boreal forest: available data and feedbacks to climate, Global Change Biol., 6(S1), 84$115,2000$.

Fahnestock, J. T., Jones, M. H., Brooks, P. D., Walker, D. A., and Welker, J. M.: Winter and early spring $\mathrm{CO}_{2}$ efflux from tundra communities of northern Alaska, J. Geophys. Res., 103(D22), 29023-29 027, 1998.

Falge, E., Baldocchi, D. D., Olson, R., et al.: Gap filling strategies for defensible annual sums of net ecosystem exchange, Agr. Forest Meteorol., 107, 43-69, 2001.

Fiedler, S., Wagner, D., Kutzbach, L., and Pfeiffer, E.-M.: Element redistribution along hydraulic and redox gradients of lowcentered-polygons, Lena Delta, Northern Siberia, Soil Sci. Soc. Am. J., 68, 1004-1011, 2004.

Flanagan, P. W. and Bunnell, F. L.: Microflora activities and decomposition, In: An Arctic Ecosystem: the Coastal Tundra at Barrow, Alaska. Dowden, edited by: Brown, J., Miller, P. C., Tieszen, L. L., et al., Hutchinson \& Ross Inc., Stroudsburg, USA, 1980.

French, H. M.: The Periglacial Environment, Longman, London, UK, 1996.

Friborg, T., Soegaard, H., Christensen, T. R., Lloyd, C. R., and Panikov, N. S.: Siberian wetlands: Where a sink is a source, Geophys. Res. Lett., 30(21), 2129, doi:10.1029/2003GL017797, 2003.

Frolov, A. D.: A review of the nature and geophysical studies of the thick permafrost in Siberia: Relevance to exploration on Mars, J. Geophys. Res., 108(E4), 8039, doi:10.1029/2002JE001881, 2003.

Fung, I. J., Tucker, C. J., and Prentice, K. C.: Applications of advanced very high resolution radiometer vegetation index to study atmosphere-biosphere exchange of $\mathrm{CO}_{2}$, J. Geophys. Res., 92, 2999-3015, 1987.

Gersper, P. L., Alexander, V., Barkley, S. A., Barsdate, R. J., and Flint, P. S.: The soils and their nutrients, in: An Arctic Ecosystem: the Coastal Tundra at Barrow, Alaska, Dowden, edited by: Brown, J., Miller, P. C., Tieszen, L. L., et al., Hutchinson \& Ross Inc., Stroudsburg, USA, 1980.

Glooschenko, W. A., Roulet, N. T., Barrie, L. A., Schiff, H. I., and McAdie, H. G.: The Northern Wetlands Study (NOWES): An overview, J. Geophys. Res., 99(D1), 1423-1428, 1994.

Gorham, E.: Northern peatlands: role in the carbon cycle and probable responses to climatic warming, Ecol. Appl., 1, 182-195, 1991.

Greco, S. and Baldocchi, D. D.: Seasonal variations of $\mathrm{CO}_{2}$ and water vapour exchange rates over a temperate deciduous forest, Global Change Biol., 2, 183-197, 1996.

Grigoriev, N. F.: The temperature of permafrost in the Lena delta basin - deposit conditions and properties of the permafrost in Yakutia (in Russian), Yakutsk, 2, 97-101, 1960.

Grigoriev, M. N.: Cryomorphogenesis of the Lena River mouth area (in Russian), Russian Academy of Science, Siberian Branch, Yakutsk, Russia, 1993.

Groendahl, L., Friborg, T., and Soegaard, H.: Temperature and snow-melt controls on interannual variability in carbon exchange in the high Arctic, Theor. Appl. Climatol., 88, 111-125, 2007.

Grogan, P., Illeris, L., Michelsen, A., and Jonasson, S.: Respiration of recently-fixed plant carbon dominates mid-winter ecosystem $\mathrm{CO}_{2}$ production in sub-arctic heath tundra, Climatic Change, 50, 
129-142, 2001.

Gu, L., Baldocchi, D. D., Wofsy, S. C., Munger, J. W., Michalsky, J. J., Urbanski, S. P., and Boden, T. A.: Response of a deciduous forest to the Mount Pinatubo eruption: Enhanced photosynthesis, Science, 299, 2035-2038, 2003.

Halldin, S., Gryning, S.-E., Gottschalk, L., Jochum, A., Lundin, L.-C., and Van de Griend, A. A.: Energy, water and carbon exchange in a boreal forest landscape - NOPEX experiences, Agr. Forest Meteorol., 98-99, 5-29, 1999.

Harazono, Y., Mano, M., Miyata, A., Zulueta, R. C., and Oechel, W. C.: Inter-annual carbon dioxide uptake of a wet sedge tundra ecosystem in the Arctic, Tellus B, 55, 215-231, 2003.

Harriss, R. C., Wofsy, S. C., Hoell, J. M., Bendura, R. J., Drewry, J. W., McNeal, R. J., Pierce, D., Rabine, V., and Snell, R. L.: The Arctic boundary layer expedition (ABLE-3B): July-August 1990, J. Geophys. Res., 99, 1635-1643, 1994.

Heide, O. M.: Dual floral induction requirements in Phleum alpinum, Ann. Bot., 66, 687-694, 1990.

Heide, O. M.:. Environmental control of flowering in some northern Carex species, Ann. Bot., 79, 319-327, 1997.

Heide, O. M.: Ecotypic variation among European arctic and alpine populations of Oxyria digyna, Arct. Antarct. Alp. Res., 37(2), 233-238, 2005

Hobbie, S. E., Nadelhoffer, K. J., and Högberg, P.: A synthesis: The role of nutrients as constraints on carbon balances in boreal and arctic regions, Plant Soil, 242, 163-170, 2002.

IPCC: Climate Change 2007: The Physical Science Basis, Contribution of Working Group I to the Fourth Assessment Report of the Intergovernmental Panel on Climate Change, edited by: Solomon, S., Qin, D., Manning, M., Chen, Z., Marquis, M., Averyt, K. B., Tignor, M., and Miller, H. L., Cambridge University Press, Cambridge, United Kingdom and New York, NY, USA, 996 pp., 2007.

Jacovides, C. P., Tymvios, F. S., Asimakopoulus, D. N., Theofilou, K. M., and Pashiardes, S.: Global photosynthetically active radiation and its relationship with global solar radiation in the Eastern Mediterranean basin, Theor. Appl. Climatol., 74, 227-233, 2003.

Johnson, L. C., Shaver, G. R., Rastetter, E., Nadelhoffer, K. J., Giblin, A., Laundre, J., Cades, D., and Stanley, A.: Plant carbonnutrient interactions control $\mathrm{CO}_{2}$ exchange in Alaskan wet sedge tundra ecosystems, Ecology, 81, 453-469, 2000.

Kattenberg, A., Giorgi, F., Grassl, H., et al.: Climate models: projections of future climate, in: Climate Change 1995: The Science of Climate Change, Contribution of Working Group I to the Second Assessment Report of the Intergovernmental Panel on Climate Change, edited by: Houghton, J. T., Meira Filho, L. G., Callender, B. A., et al., Cambridge University Press, New York, USA, 1996.

Keller, F. and Körner, C.: The role of photoperiodism in alpine plant development, Arct. Antarct. Alp. Res., 35(3), 361-368, 2003.

Kotlyakov, V. and Khromova, T.: Permafrost, Snow and Ice, in: Land Recources of Russia (CD-ROM), edited by: Stolbovoi, V. and McCallum, I., International Institute of Applied Systems Analysis and the Russian Academy of Science, Laxenburg, Austria, 2002.

Kutzbach, L.: Die Bedeutung der Vegetation und bodeneigener Parameter für die Methanflüsse in Permafrostböden (in German), Diploma thesis, University of Hamburg, Germany, 2000.
Kutzbach, L., Kurchatova, A. N., and Stoof, G.: The flora of Samoylov Island - documentation, in: Russian-German Cooperation SYSTEM LAPTEV SEA: The Expedition LENA 2002, Reports on Polar and Marine Research 466, edited by: Grigoriev, M. N., Rachold, V., Bolshiyanov, D. Y., et al., Alfred Wegener Institute, Bremerhaven, Germany, 2003.

Kutzbach, L., Wagner, D., and Pfeiffer, E.-M.: Effect of microrelief and vegetation on methane emission from wet polygonal tundra, Lena Delta, Northern Siberia, Biogeochemistry, 69, 341-362, 2004a.

Kutzbach, L., Stoof, G., Schneider, W., Wille, C., and Abramova, E. N.: Seasonal progression of active-layer thickness dependent on microrelief, in: Expeditions in Siberia in 2003, Reports on Polar and Marine Research 489, edited by: Schirrmeister, L., Alfred Wegener Institute, Bremerhaven, Germany, 2004b.

Lafleur, P. M. and Rouse, W. R.: Energy partitioning at treeline forest and tundra sites and its sensitivity to climate change, Atmos. Ocean, 33, 121-133, 1995.

Laurila, T., Soegaard, H., Lloyd, C. R., Aurela, M., Tuovinen, J.-P., and Nordstroem, C.: Seasonal variations of net $\mathrm{CO}_{2}$ exchange in European Arctic ecosystems, Theor. Appl. Climatol., 70, 183201, 2001.

Lloyd, C. R.: On the physical controls of the carbon dioxide balance at a high Arctic site in Svalbard, Theor. Appl. Climatol., 70, 167182, 2001a.

Lloyd, C. R.: The measurement and modelling of the carbon dioxide exchange at a high Arctic site in Svalbard, Global Change Biol., 7, 405-426, 2001b.

Loveland, T. R., Reed, B. C., Brown, J. F., Ohlen, D. O., Zhu, Z., Yang, L., and Merchant, J. W.: Development of a global land cover characteristics database and IGBP DISC over from $1 \mathrm{~km}$ AVHRR data, Int. J. Remote Sens., 21(6), 1303-1330, 2000.

Matthews, E.: Global vegetation and land use: New high-resolution data base for climate studies, J. Clim. Appl. Meteorol., 22, 474487, 1983.

Maxwell, B.: Recent climate patterns in the Arctic, in: Global Change and Arctic Terrestrial Ecosystems, edited by: Oechel, W. C., Callaghan, T., Gilmanov, T., et al., Springer, New York, USA, 1997.

McFadden, J. P., Eugster, W., and Chapin III, F. S.: A regional study of the controls on water vapour and $\mathrm{CO}_{2}$ exchange in arctic tundra, Ecology, 84(10), 2762-2776, 2003.

McMillen, R.: An eddy correlation technique with extended applicability to non-simple terrain, Bound.-Lay. Meteorol., 43, 231$245,1988$.

Meyer, H.: Studies on recent cryogenesis, in: Russian-German Cooperation SYSTEM LAPTEV SEA: The Expedition LENA 2002, Reports on Polar and Marine Research 466, edited by: Grigoriev, M. N., Rachold, V., Bolshiyanov, D. Y., et al., Alfred Wegener Institute, Bremerhaven, Germany, 2003.

Michaelson, G. L. and Ping, C. L.: Soil organic carbon and $\mathrm{CO}_{2}$ respiration at subzero temperature in soils of Arctic Alaska, J. Geophys. Res., 108(D2), 8164, doi:10.1029/2001JD000920, 2003.

Miller, P. C., Webber, P. J., Oechel, W. C., and Tieszen, L. L.: Biophysical processes and primary production, in: An Arctic Ecosystem: the Coastal Tundra at Barrow, Alaska, Dowden, edited by: Brown, J., Miller, P. C., Tieszen, L. L., et al., Hutchinson \& Ross Inc., Stroudsburg, USA, 1980.

Moncrieff, J. B., Massheder, J. M., de Bruin, H., Elbers, J., Fri- 
borg, T., Heusinkveld, B., Kabat, P., Scott, S., Soegaard, H., and Verhoef, A.: A system to measure surface fluxes of momentum, sensible heat, water vapour and carbon dioxide, J. Hydrol., 188189, 589-611, 1997.

Moore, C. J.: Frequency response corrections for eddy correlation systems, Bound.-Lay. Meteorol., 37, 17-35, 1986.

Natural Resources Canada: Map Canada - Permafrost, in: The National Atlas of Canada, 5th Ed., http://atlas.gc.ca/, Geological Survey of Canada, Natural Recourses Canada, Ottawa, Canada, 1995.

Nordstroem, C., Soegaard, H., Christensen, T. R., Friborg, T., and Hansen, B. U.: Seasonal carbon dioxide balance and respiration of a high-arctic fen ecosystem in NE-Greenland, Theor. Appl. Climatol., 70, 149-166, 2001.

NSIDC (National Snow and Ice Data Center): Circumpolar ActiveLayer Permafrost System, Version 2.0 (CD-ROM), edited by: Parsons, M. and Zhang, T., Boulder, USA, 2003.

Oberbauer, S. F., Starr, G., and Pop, E. W.: Effects of extended growing season and soil warming on carbon dioxide and methane exchange of tussock tundra in Alaska, J. Geophys. Res., 103, 29 075-29 082, 1998.

Oechel, W. C.: Seasonal patterns of temperature response of $\mathrm{CO}_{2}$ flux and acclimation in arctic mosses growing in situ, Photosynthetica, 10, 447-456, 1976.

Oechel, W. C., Hastings, S. J., Vourlitis, G. L., Jenkins M., Riechers, G., and Grulke, N.: Recent Change of Arctic ecosystems from a net carbon dioxide sink to a source, Nature, 361, 520-523, 1993.

Oechel, W. C., Vourlitis, G. L., and Hastings, S. J.: Cold season $\mathrm{CO}_{2}$ emission from arctic soils, Global Biogeochem. Cy., 11(2), 163-172, 1997a.

Oechel, W. C., Callaghan, T., Gilmanov, T., Holten, J. I., Maxwell, B., Molau, U., and Sveinbjornsson, B. (Eds.): Global Change and Arctic Terrestrial Ecosystems, Ecological Studies 124, Springer, New York, USA, 1997b.

Oechel, W. C., Vourlitis, G. L., Hastings, S. J., Ault Jr., R. P., and Bryant, P.: The effects of water table manipulation and elevated temperature on the net $\mathrm{CO}_{2}$ flux of wet sedge tundra ecosystems, Global Change Biol., 4, 77-90, 1998.

Oechel, W. C., Vourlitis, G. L., Hastings, S. J., Zulueta, R. C., Hinzman, L., and Kane, D.: Acclimation of ecosystem $\mathrm{CO}_{2}$ exchange in the Alaskan Arctic in response to decadal climate warming, Nature, 406, 978-981, 2000.

Panikov, N. S. and Dedysh, S. N.: Cold season $\mathrm{CH}_{4}$ and $\mathrm{CO}_{2}$ emission from boreal peat bogs (West Siberia): Winter fluxes and thaw activation dynamics, Global Biogeochem. Cy., 14(4), 1071-1080, 2000.

Panikov, N. S., Flanagan, P. W., Oechel, W. C., Mastepanov, M. A., and Christensen, T.: Microbial activity in soils frozen to below $-39^{\circ} \mathrm{C}$, Soil Biol. Biochem., 38, 785-794, 2006.

Peterson, K. M. and Billings, W. D.: Carbon dioxide flux from tundra soils and vegetation as related to temperature at Barrow, Alaska, Am. Midl. Nat., 94(1), 88-98, 1975.

Peterson, B. J., Holmes, R. M., McClelland, J. W., Vörösmarty, C. J., Lammers, R. B., Shiklomanov, A. I., Shiklomanov, I. A., and Rahmstorf, S.: Increasing river discharge to the Arctic Ocean, Science, 298, 2171-2173, 2002.

Pielke, R. A. and Vidale, P. L.: The boreal forest and the polar front, J. Geophys. Res., 100(D12), 25 755-25 758, 1995.

Ping, C. L., Michaelson, J. M., and Kimble, L. M.: Carbon storage along a latitudinal transect in Alaska, Nutr. Cycl. Agroecosys., 49, 235-242, 1997.

Polyakov, I. V., Bekryaev, R. V., Alekseev, G. V., Bhatt, U. S., Colony, R. L., Johnson, M. A., Maskshtas, A. P., and Walsh, D.: Variability and trends of air temperature and pressure in the maritime Arctic 1875-2000, J. Climate, 16, 2067-2077, 2003.

Pop, E. W., Oberbauer, S. F., and Starr, G.: Predicting vegetative bud break in two arctic deciduous shrub species, Salix pulchra and Betula nana, Oecologia, 124, 176-184, 2000.

Post, W. M., Emanuel, W. R., Zinke, P. J., and Stangenberger, A. G.: Soil carbon pools and world life zones, Nature, 298, 156159, 1982.

Pfeiffer, E.-M., Wagner, D., Kobabe, S., Kutzbach, L., Kurchatova, A., Stoof, G., and Wille, C.: Modern processes in permafrost affected soils, in: Russian-German Cooperation SYSTEM LAPTEV SEA 2000: The Expedition LENA 2001, Reports on Polar Research 426, edited by: Pfeiffer, E.-M. and Grigoriev, M. N., Alfred Wegener Institute, Bremerhaven, Germany, 2002.

Räisänen, J.: $\mathrm{CO}_{2}$-induced climate change in CMIP2 experiments: Quantification of agreement and role of internal variability, J. Climate, 14, 2088-2104, 2001.

Rocha, A. V., Su, H.-B., Vogel, C. S., Schmid, H. P., and Curtis, P. S.: The Role of Soil Moisture in Canopy Photosynthetic Responses to Diffuse Radiation in a Northern Deciduous Forest, Forest Science, 50(6), 793-801, 2004.

Rohde, H.: A comparison of the contribution of various gases to the greenhouse effect, Science, 248, 1217-1219, 1990.

Roderick, M. L., Farquhar, G. D., Berry, S. L., and Noble, I. R.: On the direct effect of clouds and atmospheric particles on the productivity and structure of vegetation, Oecologia, 129, 21-30, 2001.

ROSHYDROMET (Russian Federal Service for Hydrometeorology and Environment Monitoring): Weather Information for Tiksi, http://www.worldweather.org/107/c01040.htm, 2004.

Roulet, N. T., Moore, T. R., Bubier, J. L., and Lafleur, P.: Northern fens: methane flux and climatic change, Tellus B, 44, 100-105, 1992.

Schuepp, P. H., Leclerc, M. Y., MacPherson, J. I., and Desjardins, R. L.: Footprint prediction of scalar fluxes from analytical solutions of the diffusion equation, Bound.-Lay. Meteorol., 50, 355373, 1990.

Schwamborn, G., Rachold, V., and Grigoriev, M. N.: Late quaternary sedimentation history of the Lena Delta, Quaternary International, 89, 119-134, 2002.

Sellers, P. J., Hall, F. G., Kelly, R. D., et al.: BOREAS in 1997: Experiment Overview, Scientific Results and Future Directions, J. Geophys. Res., 102(D24), 28 731-28 770, 1997.

Serreze, M. C., Bromwich, D. H., Chapin, E. C., et al.: Observation evidence of recent change in the northern high-latitude environment, Clim. Change, 46, 159-207, 2000.

Shaver, G. R., Billings, W. D., Chapin III, F. S., Giblin, A. E., Nadelhoffer, K. J., Oechel, W. C., and Rastetter, E. B.: Global change and the carbon balance of arctic ecosystems, BioScience, 42, 433-441, 1992.

Shaver, G. R., Johnson, L. C., Cades, D. H., Murray, G., Laundre, J., Rastetter, E. B., Nadelhoffer, K. J., and Giblin, A. E.: Biomass and $\mathrm{CO}_{2}$ flux in wet sedge tundras: responses to nutrients, temperature and light, Ecol. Monogr., 68, 75-97, 1998.

Soegaard, H. and Nordstroem, C.: Carbon dioxide exchange in a 
high-arctic fen estimated by eddy covariance measurements and modeling, Glob. Change Biol., 5, 547-562, 1999.

Soegaard, H., Nordstroem, C., Friborg, T., Hansen, B. U., Christensen, T. R., Bay, C.: Trace gas exchange in a high-arctic valley, 3. Integration and scaling of $\mathrm{CO}_{2}$ fluxes from canopy to landscape using flux data, footprint modelling and remote sensing, Global Biogeochem. Cy., 14(3), 725-744, 2000.

Soil Survey Staff: Keys to Soil Taxonomy 8th Edition, Soil Conservation Service, USDA, Pocahontas, Blacksburgs, USA, 1998.

Sommerkorn, M.: Patterns and controls of $\mathrm{CO}_{2}$ fluxes in wet tundra types of the Taymyr Peninsula Siberia - the contribution of soils and mosses, Reports on Polar Research 298, Alfred Wegener Institute, Bremerhaven, Germany, 1998.

Stanhill, G. and Cohen, S.: Global dimming: a review of the evidence for a widespread and significant reduction in global radiation with discussion of its probable causes and possible agricultural consequences, Agric. Forest Meteorol., 107, 255-278, 2001.

Stocker, T. F. and Schmittner, A.: Influence of $\mathrm{CO}_{2}$ emission rates on the stability of the thermohaline circulation, Nature, 388, 862-865, 1997.

Sturm, M., Racine, C. R., and Tape, K.: Increasing shrub abundance in the Arctic, Nature, 411, 546-547, 2001a.

Sturm, M., McFadden, J. P., Liston, G. E., Chapin, P. S., Racine, C. H., and Holmgren, J.: Snow-shrub interactions in Arctic tundra: A hypothesis with climatic implications, J. Climate, 14, 336$344,2001 b$

Sveinbjörnsson, B. and Sonesson, M.: Photosynthesis and respiration in mosses and lichens, in: Global Change and Arctic Terrestrial Ecosystems, edited by: Oechel, W. C., Callaghan, T., Gilmanov, T., et al., Springer, New York, USA, 1997.

Tenhunen, D.: Diurnal and seasonal patterns of ecosystem $\mathrm{CO}_{2}$ efflux from upland tundra in the foothills of the Brooks Range, Alaska, USA, Arctic and Alpine Research, 28, 328-338, 1996.

Tieszen, L. L., Miller, P. C., and Oechel, W. C.: Photosynthesis, in: An Arctic Ecosystem: the Coastal Tundra at Barrow, Alaska, Dowden, edited by: Brown, J., Miller, P. C., Tieszen, L. L., et al., Hutchinson \& Ross Inc., Stroudsburg, USA, 1980.

Ulrich, A. and Gersper, P. L.: Plant nutrient limitations of tundra plant growth, in: Vegetation and Production Ecology of an Alaskan Arctic Tundra, edited by: Tieszen, L. L., Springer, New York, USA, 1978.

Valentini, R. (Ed.): Fluxes of Carbon, Water and Energy of European Forests, Ecological Studies 163, Springer-Verlag, Berlin, Germany, 2002.

Van Wijk, M. T., Williams, M., Laundre J. A., and Shaver, G. R.: Interannual variability of plant phenology in tussock tundra: modelling interactions of plant productivity, plant phenology, snowmelt and soil thaw, Global Change Biol., 9, 743-758, 2003 .
Vourlites, G. L. and Oechel, W. C.: Landscape-scale $\mathrm{CO}_{2}, \mathrm{H}_{2} \mathrm{O}$ vapour and energy flux of moist-wet coastal tundra ecosystems over two growing seasons, J. Ecol., 85, 575-590, 1997.

Vourlites, G. L. and Oechel, W. C.: Eddy covariance measurements of net $\mathrm{CO}_{2}$ and energy fluxes of an Alaskan Tussock tundra ecosystem, Ecology, 80(2), 686-701, 1999.

Vourlites, G. L., Harazono, Y., Oechel, W. C., Yoshimoto, M., and Mano, M.: Spatial and temporal variations in hectare-scale net $\mathrm{CO}_{2}$ flux, respiration and gross primary production of Arctic tundra ecosystems, Funct. Ecol., 14, 203-214, 2000.

Walker, H. J.: Arctic deltas, J. Coastal Res., 14(3), 71-738, 1998.

Walker, M. D., Gould, W. A., and Chapin III, F. S.: Scenarios of biodiversity change in Arctic and alpine tundra, in: Scenarios of Future Biodiversity, edited by: Chapin III, F. S., Sala, O. E., Huber-Sanwald, E., Springer, New York, USA, 2001.

Washburn, A. L.: Geocryology, A Survey of Periglacial Processes and Environments, Arnold, London, UK, 1979.

Webb, E. K., Pearman, G. I., and Leuning, R.: Correction of the flux measurements for density effects due to heat and water vapour transfer, Q. J. Roy. Meteor. Soc., 106, 85-100, 1980.

Wood, R. A., Keen, A. B., Mitchell, J. F. B., and Gregory, J. M.: Changing spatial structure of the thermohaline circulation in response to atmospheric $\mathrm{CO}_{2}$ forcing in a climate model, Nature, 399, 572-575, 1999.

Zamolodchikov, D. G. and Karelin, D. V.: An empirical model of carbon fluxes in Russian tundra, Glob. Change Biol., 7(2), 147161,2001

Zamolodchikov, D. G., Karelin, D. V., Ivaschenko, A. I., Oechel, W. C., and Hastings, S. J.: $\mathrm{CO}_{2}$ flux measurements in Russian Far East tundra using eddy covariance and closed chamber techniques, Tellus B, 55(4), 879-892, 2003.

Zhang, T., Barry, R. G., Knowles, K., Heginbottom, J. A., and Brown, J.: Statistics and characteristics of permafrost and ground-ice distribution in the Northern hemisphere, Polar Geogr., 23(2), 132-154, 1999.

Zimov, S. A., Zimova, G. M., Davidov, S. P., et al.: Winter biotic activity and production of $\mathrm{CO}_{2}$ in Siberian soils: a factor in the greenhouse effect, J. Geophys. Res., 98, 5017-5023, 1993.

Zimov, S. A., Voropaev, Y. V., Semiletov, I. P., Davidov, S. P., Prosiannikov, S. F., Chapin III, F. S., Chapin, M. C., Trumbore, S., and Tyler, S.: North Siberian lakes: a methane source fueled by Pleistocene carbon, Science, 277, 800-802, 1997.

Zhuang, Q., Melillo, J. M., Sarofirm, M. C., Kicklighter, D. W., McGuire, A. D., Felzer, B. S., Sokolov, A., and Prinn, R. G.: $\mathrm{CO}_{2}$ and $\mathrm{CH}_{4}$ exchanges between land ecosystems and the atmospheres in northern high latitudes over the 21 st century, Geophys. Res. Lett., 33, L17403, doi:10.1029/2006GL026972, 2006. 